\title{
The last 100 million years on the Scotian Margin, offshore eastern Canada: an event-stratigraphic scheme emphasizing biostratigraphic data
}

\author{
Robert A. Fensome ${ }^{*}$, Jason A. Crux ${ }^{2,3}$, I. Gunilla Gard ${ }^{2,3}$, R. Andrew MacRae ${ }^{4}$, \\ Graham L. Williams ${ }^{1}$, Frank C. Thomas ${ }^{1}$, Flavia Fiorini ${ }^{5,6}$ and Grant Wach ${ }^{5}$ \\ 1. Natural Resources Canada, Geological Survey of Canada (Atlantic), Bedford Institute of Oceanography, \\ P.O. Box 1006, Dartmouth, Nova Scotia, B2Y 4A2 Canada \\ 2. Biostratigraphic Associates (Canada) Inc., 5915 Mesa Brook Lane, Houston, Texas 77041, USA \\ 3. Current address: BHP Billiton, 1360 Post Oak Boulevard, Suite 150, Houston, Texas 77056, USA \\ 4. Department of Geology, Saint Mary's University, Halifax, Nova Scotia, B3H 3C3 Canada \\ 5. Department of Earth Sciences, Dalhousie University, Halifax, Nova Scotia, B3H 4J1 Canada \\ 6. Present address: Smithsonian Tropical Research Institute, Center for Tropical Paleoecology \\ and Archeology (CTPA), Ancon, Panama, Republica de Panama \\ *Corresponding author: <rfensome@nrcan.gc.ca $>$
}

Date received: 07 May 2008 I Date accepted 04 September 2008

\begin{abstract}
In order to provide a detailed stratigraphic framework for the Late Cretaceous and Cenozoic basin fill of the Scotian Margin (the continental shelf and continental slope off Nova Scotia, eastern Canada), we have developed an eventbiostratigraphic scheme based mainly on new analyses of several exploration wells. They include Demascota G-32, Hesper I-52, Onondaga E-84 and Wenonah J-75 on the continental shelf, as well as Shelburne G-29 and Shubenacadie $\mathrm{H}-100$ on the continental slope. Several microfossil groups are involved in this study, most notably dinoflagellate cysts (dinocysts) and nannofossils, with the former generally providing more diverse assemblages and the latter more precise calibration with global correlations. Because most of the material studied is from cuttings samples, we have relied largely on last appearance datums (LADs). The scheme incorporates information from about 250 microfossil species (or groups of species), delimiting about 180 events, of which about 50 percent are based on nannofossils, some 46 percent on palynomorphs and 4 percent on foraminifera. Not all events occur in all wells and the scheme needs to be tested against future observations: nevertheless, it represents a considerable advance on previous schemes, which were based mostly on broad zones rather than detailed events. Moreover, it allows for a more refined assessment of ages of geological events, such as the late Paleocene gamma spike and the incision of the Wenonah Canyon. And it provides an accurate age context for ongoing stratigraphic, sedimentological and paleoenvironmental studies, and ultimately for a fuller understanding of petroleum systems on the Scotian Margin.
\end{abstract}

RÉSUMÉ

Pour fournir un cadre stratigraphique détaillé du remplissage du Crétacé tardif et du Cénozoïque du bassin de la marge Néo-Écossaise (plateau continental et pente continentale au large de la Nouvelle-Écosse, est du Canada), nous avons mis au point une formule événementielle-biostratigraphique principalement basée sur de nouvelles analyses de plusieurs puits d'exploration. Ces derniers comprennent les puits Demascota G-32, Hesper I-52, Onondaga E-84 et Wenonah J-75 sur le plateau continental ainsi que Shelburne G-29 et Shubenacadie H-100 sur la pente continentale. L'étude touche plusieurs groupes de microfossiles, plus particulièrement les kystes de dinoflagellés (dinokystes) et les nannofossiles, les premiers procurant généralement des assemblages plus diversifiés et les derniers, un étalonnage plus précis avec des corrélations mondiales. Comme la majeure partie du matériel étudié provient d'échantillons de déblais, nous nous sommes largement appuyés sur les plans de référence des dernières manifestations. La formule incorpore des données provenant d'environ 250 espèces (ou groupes d'espèces) de microfossiles délimitant quelque 180 phénomènes, dont environ $50 \%$ sont basés sur des nanofossiles, quelque $46 \%$ sur des palynomorphes et $4 \%$ sur des foraminifères. Les phénomènes en question ne se manifestent pas tous dans tous les puits et il faut encore soumettre la formule à des essais en vertu des observations futures: elle représente néanmoins un progrès considérable par rapport aux formules antérieures, qui étaient surtout basées sur des zones étendues plutôt que sur des phénomènes détaillés. 
Elle permet de plus une évaluation plus raffinée des âges des phénomènes géologiques, comme les pics gamma du Paléocène tardif et l'incision du canyon Wenonah. Elle procure par ailleurs un contexte de datation exact pour les études stratigraphiques, sédimentologiques et paléoenvironnementales courantes, et elle permettra en fin de compte une compréhension plus complète des systèmes pétroliers le long de la marge Néo-Écossaise.

\section{[Traduit par la redaction]}

\section{INTRODUCTION}

The Scotian Margin comprises the continental shelf and slope off Nova Scotia, southeastern Canada (Fig. 1). Its geology was virtually unknown until petroleum exploration, beginning in the 1960s, revealed more than $18 \mathrm{~km}$ of basin fill (Wade and MacLean 1990). Biostratigraphy confirmed that these strata range in age from Late Triassic to Holocene, and biostratigraphy continues to be the main source of age control and correlation on the Margin.

Rich assemblages of several microfossil groups have been recovered from exploration wells on the Scotian Margin and have formed the basis for biostratigraphic and related studies. These microfossils include organic-walled forms (palynomorphs) such as dinoflagellate cysts (dinocysts), acritarchs (organic-walled protist microfossils of uncertain affinity) and vascular plant spores and pollen (miospores), and "shelly" microfossils such as foraminifera, ostracods, radiolarians and calcareous nannofossils. Of these groups, the most useful in the Late Cretaceous-Cenozoic interval are calcareous nannofossils, dinocysts and foraminifera. Rare macrofossils in conventional core, such as inoceramid bivalves and ammonites, can provide additional information.

Among palynomorphs in Mesozoic-Cenozoic rocks, acritarchs are uncommon and less diverse than dinocysts, but some species are useful for biostratigraphy. Miospores, which principally derive from terrestrial plants but are transported through the atmosphere and/or ocean into marine sediments, are commonly abundant, but their taxonomy and biostratigraphy are not as well documented and constrained as the taxonomy and biostratigraphy of dinocysts. Hence, in palynomorph-based biostratigraphy of predominantly marine Mesozoic-Cenozoic strata, acritarchs and miospores generally play a secondary role to dinocysts. These aspects were borne out during the present study, with dinocysts providing all but a few of the palynomorph events. With further study, the miospores, especially angiosperm pollen, have the potential to provide additional useful events.

The first palynomorph-based biostratigraphic scheme for the Scotian Margin was that of Williams (1975): it included 16 zones for the Late Cretaceous-Cenozoic interval, each approximately equivalent to a stage. All but one of the zone names were based on dinocysts. Williams provided lists of taxa that were diagnostic for each zone, but did not detail events within the zones. This zonation scheme was further refined in Williams and Bujak (1977-for the Cenozoic) and Bujak and Williams (1978-for the Cretaceous). The scheme was applied to 23 Scotian Margin wells by Barss et al. (1979), with results summarized in the Scotian Shelf Basin Atlas (coordinated by Cant 1991).

Calcareous nannofossils have received limited attention on the Scotian Margin. The only significant published work is that by Doeven (1983), who studied the Albian through Maastrichtian interval in 11 wells from the area. He defined 16 zones which compare closely with previous world-wide nannofossil zonation schemes, notably that of Sissingh (1977). Since then, calcareous nannofossils have been extensively studied in all marine environments, and chronostratigraphic refinement and precision have greatly improved. Of particular importance are studies of ocean sediments through the Deep Sea Drilling and Ocean Drilling programs (DSDP and ODP). These studies have facilitated the correlation of nannofossil events to magnetostratigraphy, as well as to schemes based on other microfossil groups (Berggren et al. 1995; Bown 1998; Hardenbol et al. 1998).

Foraminifera can be divided into benthic and planktic forms: the former are more valuable in paleoecological studies because of their narrow facies adaptations and the generally long ranges of individual species; the latter are generally more useful for biostratigraphy because of wide distribution and relatively rapid evolution. The data used in this study are from both planktics (Caron 1985; Toumarkine and Luterbacher 1985; Bolli and Saunders 1985) and certain benthic species found to be useful regional markers (Gradstein and Agterberg 1982).

Integration of zonation schemes developed for different fossil groups is often challenging, especially when biostratigraphic control is based mainly on cuttings samples from wells, which are subject to downhole contamination. To avoid this problem and improve resolution, we have developed an event biostratigraphy for the Late Cretaceous-Cenozoic of the Scotian Margin. Biostratigraphic events are generally the oldest (first) or youngest (last) occurrence of a particular species, though a flood or peak occurrence can also be used if it can be shown to be essentially coeval throughout the region. We refer to horizons marking oldest/first occurrences as "first appearance datums" or FADs; and to horizons referring to youngest/last occurrences as "last appearance datums" or LADs. Because our data are almost exclusively from cuttings, the majority of the events that we have used are last occurrences. The advantage of using events rather than zones is that they allow for more refined age control and quantification of ages using a standard time scale (e.g., Gradstein et al. 2005), and we can better integrate events from different sources, including those from lithostratigraphic data from cuttings and cores, petrophysical information and seismic data. 


\section{GEOLOGICAL SETTING}

In this study we have considered material from Albian through Pliocene, an interval that spans the Logan Canyon, Dawson Canyon, Wyandot and Banquereau formations of McIver (1972) and Jansa and Wade (1975) (Fig. 2). A brief history of the Mesozoic-Cenozoic rocks of the Scotian Margin is provided below, and is based on Wade and MacLean (1990) and this study.

The outer Scotian Margin is underlain by the Scotian Basin, which in some areas contains strata more than $18 \mathrm{~km}$ thick and roughly parallels the shelf break from the southern Grand Banks in the northeast to Georges Bank in the southwest (Fig. 1). Like other Mesozoic-Cenozoic basins along the mid North Atlantic margins, the basin was initiated by rifting, and the earliest deposits in the Late Triassic and Early Jurassic consist of terrestrial rift sediments and basalts that are broadly equivalent to the onshore Fundy Group. In offshore areas, terrestrial red beds in the Eurydice Formation intertongue with marine evaporites, mainly halite, of the Argo Formation (Fig. 2). Because of sediment loading, consequent mobilization of the Argo Formation resulted in the salt tectonism that affects much of the Scotian Margin (Shimeld 2004).

The generation of oceanic crust in the early Middle Jurassic began the drift phase of margin evolution. For most of the remaining Jurassic, deposition was dominated by deltaic and marine clastic sediments of the Mohican, Mic Mac and Mohawk formations, especially in the vicinity of Sable Island and areas to the northeast, while the area to the southwest was dominated by carbonate bank deposition, as represented by the Abenaki Formation. In the Early Cretaceous, the sedimentary system became dominated by deltaic clastics in the
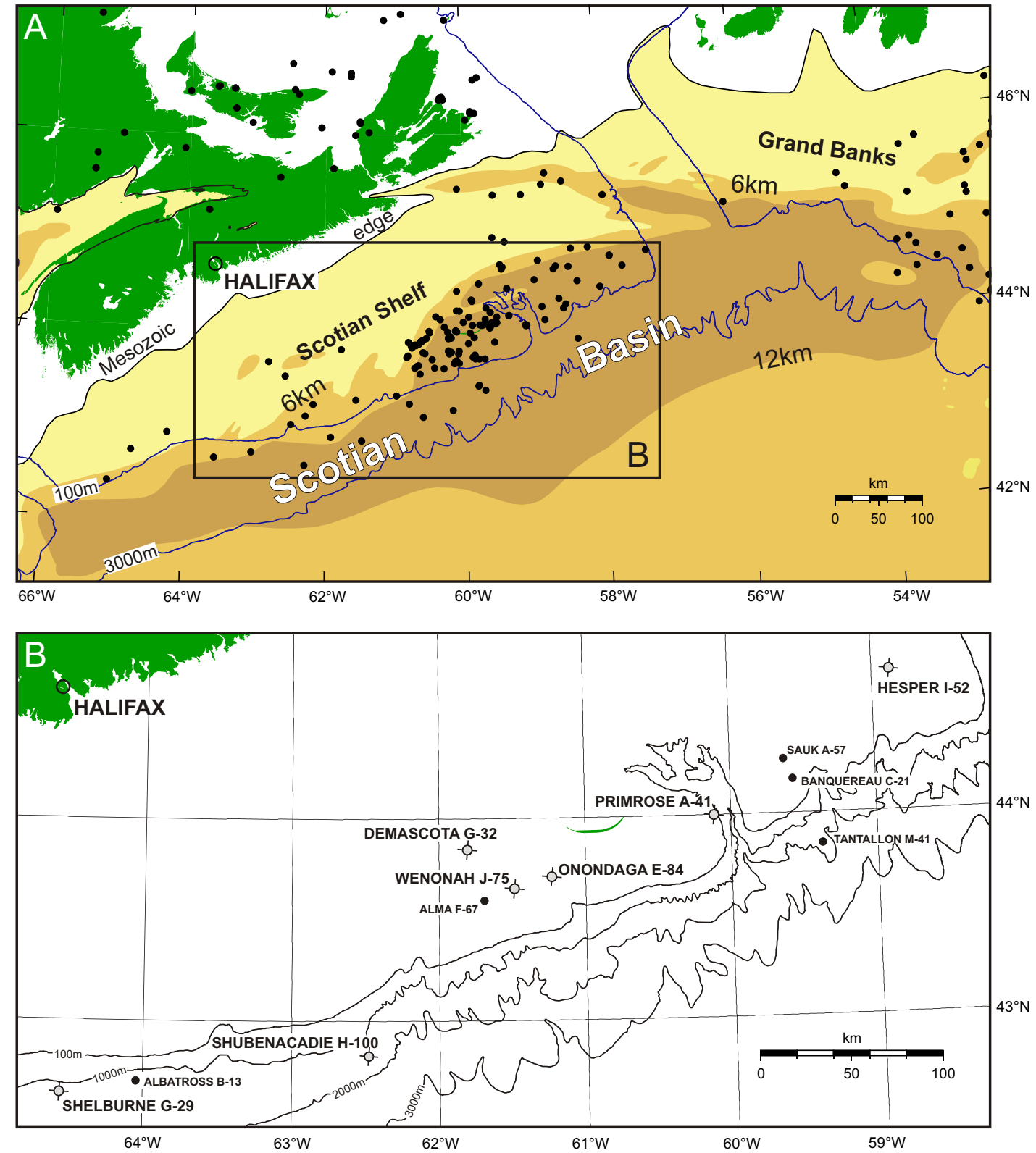

Fig. 1. A. Location map showing the Scotian Basin, with exploration wells shown as black dots. The yellow-brown shading indicates depth to basement, with the actual depths indicated in kilometres $(\mathrm{km})$. Outline of the Scotian Basin and basement depths based on Williams and Grant (1998).

B. The wells primarily examined for this study for which well plots are provided in the appendices (larger text and well symbol), plus those wells also mentioned in the text (smaller text and black dots). 


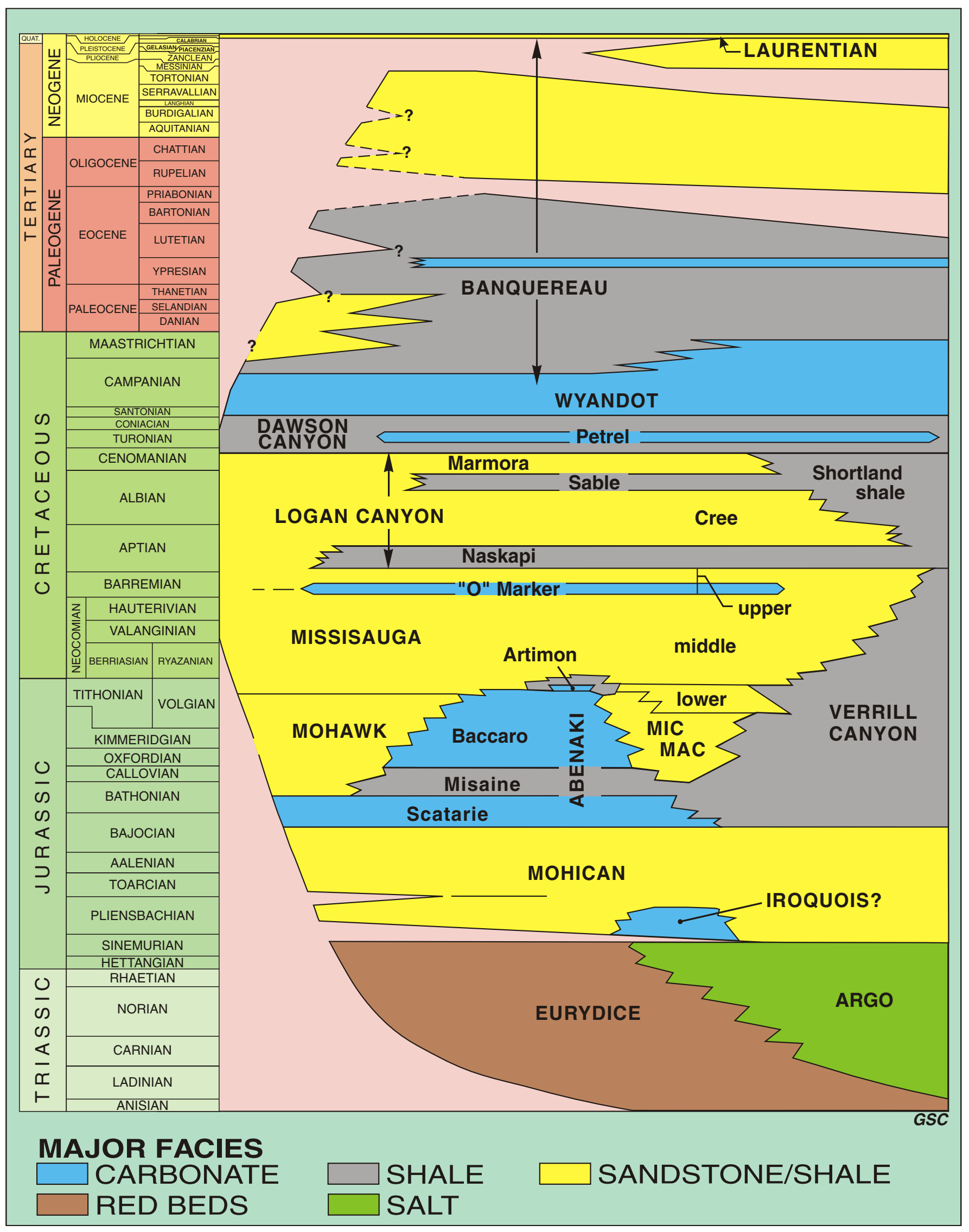

Fig. 2. Generalized stratigraphy of the Scotian Margin, modified from MacLean and Wade (1993). Formations are in upper case script and members in lower case script. 
Missisauga Formation, the most productive hydrocarbon reservoir in the region. The distal equivalent of both the Jurassic Mic Mac and Abenaki formations and the Lower Cretaceous Missisauga Formation is the mudstone-dominated Verrill Canyon Formation, thought to be the main petroleum source rock for the area (Powell 1982). Above the Missisauga and Verrill Canyon formations is the Logan Canyon Formation, a broadly transgressive unit as compared to the earlier clastic systems. The Logan Canyon Formation is divided into four members: the mudstone-dominated Naskapi Member, the sandstone-dominated Cree Member, the mudstone-dominated Sable Member, and the sandstone-dominated Marmora Member. Distally, the deep-water equivalent unit is the informal Shortland shale (Jansa and Wade 1975). Biostratigraphy indicates the Logan Canyon Formation spans the Aptian through Cenomanian (Williams et al. 1990), and the upper part of the Logan Canyon Formation is the oldest interval considered in this study.

In the Late Cretaceous, the mudstone-dominated Dawson Canyon Formation and the chalk- and- marlstone-dominated Wyandot Formation continue the trend of waning coarse clastic sedimentation. It is tempting to interpret this as a local expression of the long-term eustatic sea-level high that occurred in the Late Cretaceous (Miller et al. 2005), although regional changes in tectonics and sediment supply may be as important. Within the Dawson Canyon Formation is a laterally extensive limestone unit, the Petrel Member, which occurs on both the Scotian Margin and the Grand Banks. The Petrel Member is Turonian-Coniacian in age (Doeven 1983), and the Dawson Canyon Formation as a whole spans the Cenomanian to as young as earliest Maastrichtian, although in most areas its top is within the Coniacian. The contact between the Dawson Canyon and Wyandot formations is diachronous, mainly because the chalks of the Wyandot Formation thin and intertongue with mudstones of the Dawson Canyon Formation to the northwest, toward the landward erosive edge of the basin. In addition to variation in the oldest age of the Wyandot Formation, its top varies from Santonian to Maastrichtian because of erosional truncation (MacRae et al. 2003). The thickest and temporally most complete sections of the Wyandot Formation occur on the northeastern Scotian Shelf and the upper Scotian Slope, where it is more than $500 \mathrm{~m}$ thick.

The succession from the top of the Wyandot Formation to the approximate base of glacial erosion in the early to middle Pleistocene comprises the Banquereau Formation, which consists of mudstones, sandstones, and thin chalks. Although Hardy (1975) defined four informal members, they have been used only rarely. Deptuck et al. (2003) formally subdivided part of the Banquereau Formation in the Jeanne d'Arc Basin on the Grand Banks. There, the absence of the Wyandot Formation over most of the region leads to difficulty in separating mudstones of the Dawson Canyon Formation from those of the basal Banquereau Formation. The problem was resolved by earlier workers with the adoption of the Cretaceous/Cenozoic boundary as a proxy, a convention followed by Deptuck et al. (2003). However, it is important to realize that this conven- tion doen not work on the Scotian Margin, where the basal Banquereau Formation includes much of the Maastrichtian and possibly part of the Campanian in some areas. Therefore some reconciliation of Scotian Margin and Grand Banks nomenclature will be necessary in the future.

On the Scotian Margin, the Banquereau Formation has several mappable stratigraphic units and events. Broadly, the formation consists of a lower interval of prograding deltaic clinoform units that built basinward over the underlying Wyandot erosion surface (Fig. 3). Topsets consist of sandstone, whereas foresets and bottomsets are mainly mudstone. These units span at least the Maastrichtian through Paleocene. Above is a mudstone and chert unit, followed by a thin, early Eocene chalk, which forms a mappable seismic marker over much of the outer shelf and slope (Fig. 3). Additional chalk units occur on the Scotian Slope in the Paleocene. Canyon incision at the shelf edge started in the Eocene, but became particularly extensive in the Oligocene. One of the Oligocene canyons is penetrated by the Wenonah J-75 well, a subject of this study and previous work by Thomas (2005). In the post-Oligocene, the Banquereau is increasingly sandy in more landward sections and consists of seaward-stepping progradational episodes punctuated by canyon incision and broader erosion, culminating with the effects of Pleistocene glacial erosion. Analysis of material near the top of this interval is hindered by the surface casing of the upper parts of most exploration wells in the area.

\section{BIOSTRATIGRAPHIC APPROACH AND DISCUSSION}

Our principal aim in this paper is to develop an integrated scheme of events and thus refine the age control of the Upper Cretaceous and Cenozoic strata of the Scotian Margin. Most recent biostratigraphic studies of the Scotian Margin use palynomorphs, principally dinocysts, and so they provide the basis for the present study. The principal non-palynomorph information source is nannofossils. Cosmopolitan nannofossil events, well-established in deep-sea studies, provide an important calibration of the palynomorph events. In our study, middle Cretaceous to Cenozoic palynomorphs have been examined from the following wells: Demascota G-32, Hesper I-52, Onondaga E-84, Shelburne G-29, Shubenacadie H-100 and Wenonah J-75. The detailed results of these analyses can be found in Geological Survey of Canada (Atlantic) internal reports (Fensome 2000, 2001, 2002, 2003a, 2003b, 2003c) and are summarized and updated in Appendices 2-7. Assemblages from Late Cretaceous strata from conventional cores in Primrose A-41 were also examined (Appendix 8). In addition, we have incorporated palynomorph data from Wade et al. (1995), who analyzed the early Cenozoic in three wells (Sauk A-57, Banquereau C-21 and Tantallon M-41) that provide a transect from the Scotian Shelf to the Scotian Slope. Wade et al. used the biostratigraphic events to correlate between 

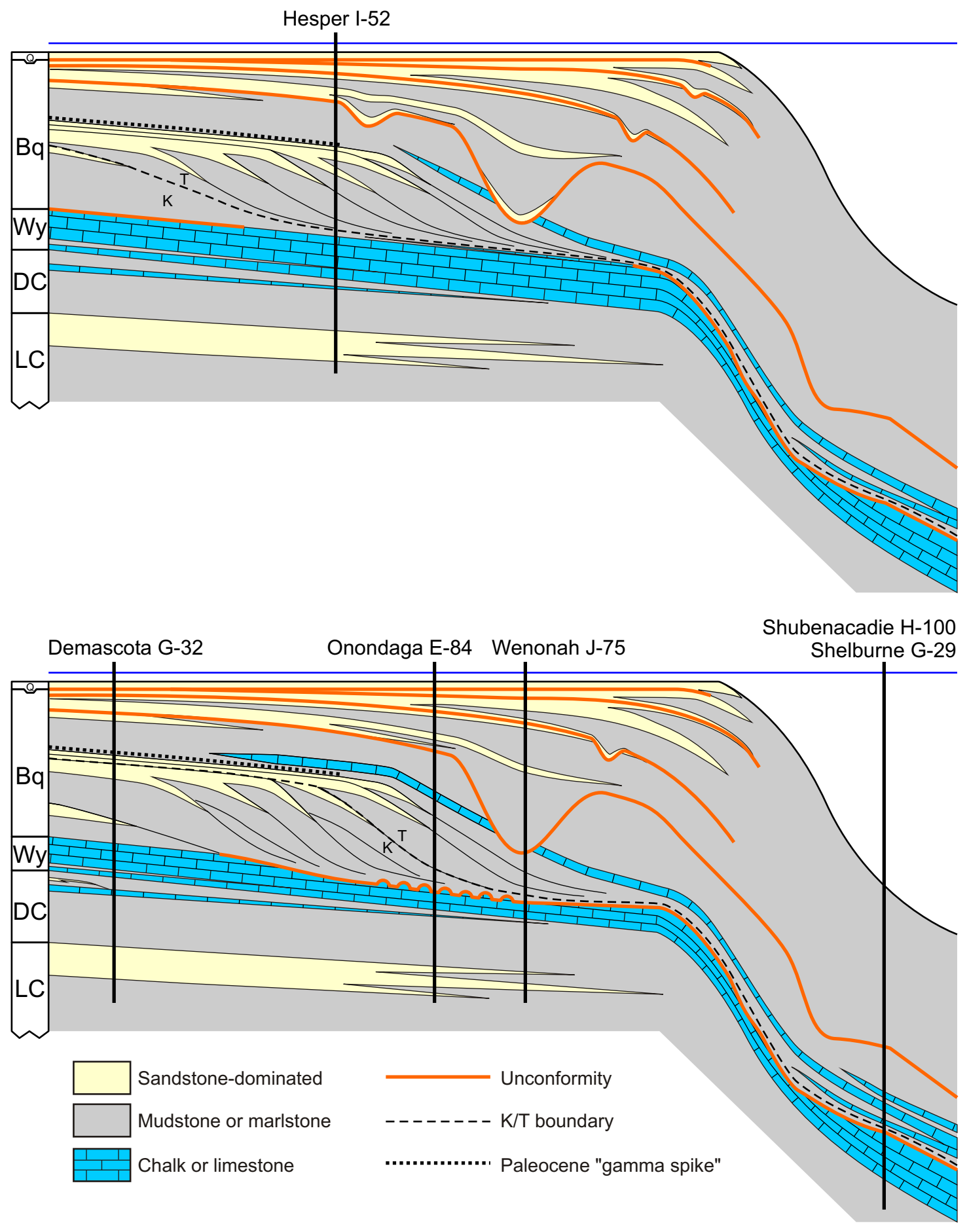

Fig. 3. The general stratigraphy in the Upper Cretaceous-Cenozoic interval of the Scotian Margin in two dip sections, showing the relative location of most of the wells in this study. Well locations are approximate and only generally representative of their actual geographic locations and stratigraphy. Sections are not to scale and faults displacing this part of the section are not shown. The upper section represents the general stratigraphy on the northeastern Scotian Margin, the lower section represents the general stratigraphy just to the southwest of Sable Island. Note the differing timing and magnitude of lower Banquereau Formation progradation on the southwest versus northeast part of the margin (mainly Paleocene in the northeast, and Maastrichtian in the southwest), and the presence of significant erosion at the top contact of the Wyandot Formation. $\mathrm{K}$ indicates uppermost Cretaceous units and T indicates lowermost Tertiary units. Lithostratigraphic unit key: $\mathrm{LC}=$ Logan Canyon Formation; DC = Dawson Canyon Formation (limestone unit within is the Petrel Member); Wy = Wyandot Formation; $\mathrm{Bq}=$ Banquereau Formation; $\mathrm{Q}=$ Quaternary sediments. 
Scotian Margin seismic reflectors and those of the deep-water North Atlantic Basin.

Benthic and planktic foraminifera in cuttings samples and a few sidewall cores have also been studied from the Cenozoic sections of Hesper I-52, Onondaga E-84, Shelburne G-29, Shubenacadie H-100 and Wenonah J-75. Additionally, the Cretaceous interval of Hesper I-52 has been analyzed. The biostratigraphic successions of these wells have been described (Thomas 1991, 2001, 2003a, b, c), based in part on the regional benthic foraminiferal zonation of Gradstein and Agterberg (1982), and on standard planktic foraminiferal schemes (Caron 1985; Toumarkine and Luterbacher 1985; Bolli and Saunders 1985), allowing for the recognition of several foraminiferal events that are incorporated into the present work.

We analyzed nannofossil assemblages from middle Cretaceous through Cenozoic strata in Demascota G-32, Shelburne G-29 and Shubenacadie H-100. We also examined the Oligocene section (840-1400 m) in Wenonah J-75. We used sidewall cores and conventional cores where available, but often only had cuttings. Unpublished results from industrial studies by one of us (JAC) of additional wells, including Albatross B-13, Alma F-67 and Tantallon M-41, on both shelf and slope, were used to refine the stratigraphy. Thus, although numerous nannofossil datums have been observed, insofar as the nannofossils are concerned the present study is limited by the relatively few analyzed well sections, which may not have sampled all time intervals present on the Scotian Margin.

Biostratigraphic application in a given basin or region can be thought of as a three-step process: 1) establishment of a local succession, for example in a single well; 2) correlation within a regional context; and 3) calibration with an international chronostratigraphic time scale. The focus of the present work is to undertake this third step for the Scotian Margin but, before this can be done, problems with the first two steps must be discussed.

On the Scotian Margin several factors need to be considered in recognizing a local stratigraphic succession in a single well. Reworking is always a potential problem, but can commonly be spotted because of differences in the preservation and abundance of reworked specimens; rareness of particular species at the top of their ranges must always be treated with caution. More importantly, generally only cuttings samples are available, and hence LADs are more reliable than range bottoms (FADs). The few conventional cores, available from Shubenacadie H-100 and Primrose A-41 wells, were examined, and proved useful for calibration. Sidewall cores were helpful for some wells, notably Wenonah J-75 for palynology and Shelburne G-29 and Alma F-67 for nannofossils, but after geological and reservoir-engineering studies, generally insufficient material was left for biostratigraphy.

Once information from several wells had been established, it was possible to correlate events across the region. However, because of paleoenvironmental variation and local to regional stratigraphic gaps, not all events are present in all wells. Although the wells for this study are all on the outer shelf or on the slope, Wenonah J-75, is located in a canyon and thus prone to influxes of sediment from landward. This situation is clearly reflected in the fossil assemblages. For example, Thomas (2005) noted that benthic foraminiferal assemblages in sidewall core samples from the Oligocene section of Wenonah J-75 are unusual, reflecting unique environmental parameters (upwelling, tidal currents, or perhaps unstable ocean chemistry) in this deep canyon. In the present study, the dinocyst assemblages in Wenonah J-75 generally tended to reflect a more nearshore setting, possibly due to down-canyon sediment influx: for example, some Oligocene samples yielded abundant specimens of Homotryblium plectilum, a species that is generally considered to be a nearshore form (Dybkjaer 2004).

Even though paleoecological differences are in some cases apparent, it is puzzling that for planktic forms such as dinoflagellates (motile cells live in the water column, though cysts usually settle to the bottom), distributions are not consistently widespread. For example, why are species such as Homotryblium plectilum, Mendicodinium? robustum and Apectodinium homomorphum abundant in some wells and rare or absent in others? Does this inconsistency reflect different distribution patterns related to onshore-offshore settings and prevailing currents, or does it reflect missing section? For example, Shubenacadie H-100 seems to exhibit a fairly complete section across the Cretaceous-Paleocene transition, with boundary-related forms such as Cyclapophysis monmouthensis and Palynodinium grallator common; in other wells, these species are generally absent, presumably because boundary beds are absent or sections are so condensed that their distribution falls between sample intervals. The latter interpretation is consistent with the stratigraphy of the boundary interval at the other studied well locations (Fig. 3).

Before any meaningful application of fossils to biostratigraphic, paleogeographic, or paleoenvironmental interpretations can be made, an accurate understanding and communication of the species concepts is essential. Hence, Fensome et al. (in press) is intended as a companion paper to this one, updating the taxonomy of many Scotian Margin palynomorphs (mainly dinocysts). Because of this update, numerous new taxa and concepts are now formally available for use in the event stratigraphy presented in this paper.

Oceanographic studies have played a leading role in the recent development of the chronostratigraphic scale, especially through the development of schemes based on microfossils and their relationship to the paleomagnetic scale (Berggren et al. 1995; Hardenbol et al. 1998; Gradstein et al. 2005). As widespread microfossils in oceanic environments, nannofossils have played a significant role in standardizing oceanic time scales, and hence have been vital in calibrating events defined in this paper. Although of more limited oceanic distribution, dinocysts are more widespread and diverse than nannofossils in shelf and slope environments, and great efforts have recently been made to constrain and calibrate their ranges using data from European type sections and comparisons with oceanic-based nannofossil schemes (Williams et al. 1999, 2004). Although stratigraphic ranges in a particular basin such as the Scotian 
Basin do not necessarily match the full extent of international ranges, the latter are a fundamental starting point.

\section{LITHOSTRATIGRAPHIC EVENTS}

In addition to biostratigraphic events, several lithostratigraphic events are distinctive and brief enough to serve as useful markers for correlation in the region. In particular, a distinctive "gamma ray spike" 3-4 $\mathrm{m}$ thick and with gamma ray readings greater than 100 API units occurs in numerous wells in the topsets of the progradational lower part of the Banquereau Formation. In many respects this feature is similar to an approximately coeval event described by Deptuck et al. (2003) on the Grand Banks. In the present study, the event was penetrated at the Demascota and Hesper wells where, according to biostratigraphic data, it is Late Paleocene in age. A second "gamma spike" with similar log character occurs near the Oligocene-Miocene boundary, but its exact age is not well constrained and it is not laterally persistent.

Biostratigraphy indicates an early Eocene (Ypresian) age for a thin $(20-50 \mathrm{~m})$, widespread chalk unit penetrated at Onondaga E-84 and observed at other wells in the region (see MacLean and Wade 1993). On seismic profiles, this chalk produces a widespread reflection that is locally truncated by canyon erosion just before reaching the Wenonah J-75 well (see Figure 3). Thus, the strata immediately below the canyon erosion surface are from an interval stratigraphically below the chalk. In Wenonah J-75, this sub-erosion interval is biostratigraphically dated as Ypresian, implying that the age of the chalk unit (though not actually intersected in the well) lies within the Ypresian rather than at its base. Chalk deposition may have persisted longer on the Scotian Slope, where there are several chalk units in the Paleocene and Ypresian intervals in the Shelburne and Shubenacadie wells. In the Onondaga E84 well, the chalk interval (about 1077-1120 m) is expressed as a chalky mudstone that produces a slightly lower gamma-ray response (Appendix 4) and a higher sonic velocity (not shown). Here, in contrast to correlations in other wells, the age of the chalk appears to extend down into the uppermost Paleocene, but is constrained only by a single sample. Only further study will help resolve this inconsistency.

\section{TIME SCALES AND THE CURRENT EVENT SCHEME}

Correlation between individual localities within an area will provide a regional biostratigraphic framework. But for a broader context, the regional scheme must be tied to the global chronostratigraphic scheme that is based on internationally-agreed type sections, usually through use of chronostratigraphic-unit names such as Ypresian (Early Eocene). The resolution that we are aiming for is best served by use of the numerical calibration of these units in millions of years. Use of such numbers, often down to a ten-thousand-year scale, may give a false impression of precision at times, but is needed to separate what appear to be closely spaced but probably not synchronous events.

A second problem with this approach is that numerical values change as the geological time scale is refined. Initially we used the time scale published by Hardenbol et al. (1998) because it provided worldwide and detailed stratigraphic datums for the fossil groups used in this study (palynomorphs, calcareous nannofossils and foraminifera). And it allowed correlation to macrofossil zones, magnetostratigraphy and sequence stratigraphy. However, during the course of this work, the new Geological Time Scale (GTS 2004) was published (Gradstein et al. 2005), making it necessary to convert our ages to the new standard. Several types of modification were involved in the development of GTS 2004 with respect to earlier time scales. In some cases, the physical boundary has been changed: an example is the Paleocene-Eocene boundary, which has been redefined as the horizon of the global carbon isotope excursion, now dated at $55.8 \mathrm{Ma}$ and stratigraphically lower than the previous definition of the boundary (Gradstein et al. 2005). Some events, including many nannofossil zone boundaries in the Cenozoic, have been re-calibrated against magnetochrons. The timing of other events has been mathematically recalculated to conform to repositioned boundaries, as in the Late Cretaceous.

Nannofossil events useful for dating sediments on the Scotian Margin are cosmopolitan and most are widely used in other areas. In general, Scotian Margin nannofossil events correspond to their distribution in the Tethyan realm. Tertiary nannofossil datums are based on the work by Berggren et al. (1995) and absolute ages from these sources provide fundamental information for the present study, with the subsequent conversions to GTS 2004. These ages were compiled from occurrences in which the nannofossil datums could be directly tied to magnetostratigraphy.

The Cretaceous nannofossil datums are less well constrained and their position on the Hardenbol et al. (1998) scale is less refined. Absolute ages for nannofossil events from other sources are derived through correlation with stage boundaries, biostratigraphic zonal boundaries, and/or magnetostratigraphy that are part of the GTS 2004 time scale, which provides a calibration of key nannofossil events. The number of other sources has been deliberately limited, where possible, to several widely used compilations that should be internally consistent (PerchNielsen 1985a, b; Berggren et al. 1995; Bown 1998). It should be noted that these references are not primary data sources and thus correlations to magnetostratigraphy are indirect.

Ages of the palynomorph (mainly dinocyst) events have been derived in two principal ways: either in direct relation to nannofossil events on the Scotian Margin; or from careful determinations provided in the literature, which are usually in turn based on nannofossil or magnetostratigraphic calibrations (Williams et al. 1999, 2004).

The proposed event scheme for the Scotian Margin is shown in Fig 4, and justifications for individual events are listed below in chronological order going backwards in time within the 


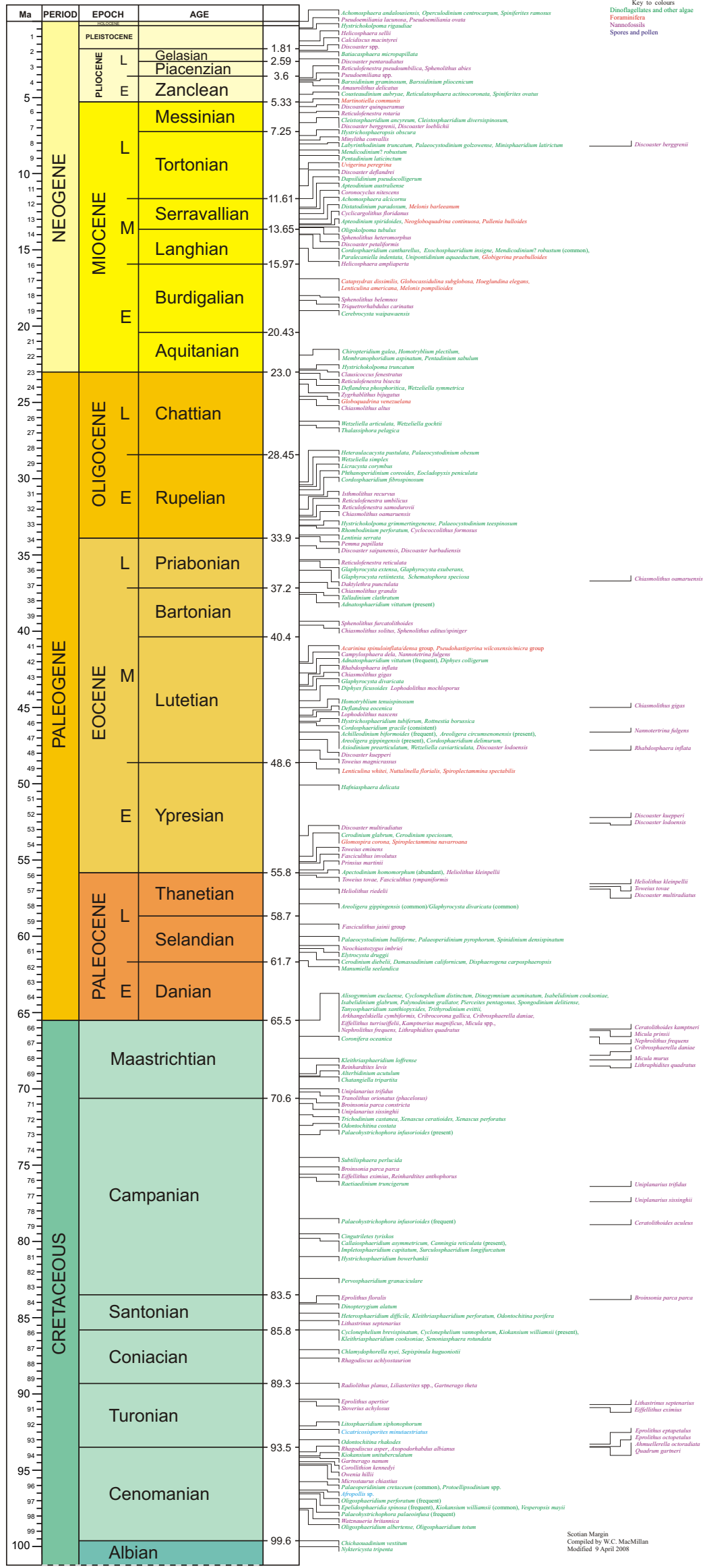

Fig. 4. Summary of the event biostratigraphy described in this paper. Last occurrence datums (LADs) are indicated on the left, first occurrence datums (FADs) are on the right; nannofossils are indicated in purple, dinocysts in green, and foraminifera in orange. Some events are further qualified based on their abundance (see text for details of individual events). The time scale on the left edge of the chart is based on Gradstein et al. (2005). The authors may be contacted for larger printed versions of this figure. 
listing for each microfossil group. Authorships for taxonomic names are provided in Appendix 1. Taxonomic treatment of the palynomorph taxa can be found in a companion paper, Fensome et al. (in press). Palynomorphs are dinocysts except where otherwise stated. All the nannofossil events described below have been observed on the Scotian Margin.

\section{Nannofossils}

Absolute ages for the nannofossil events from sources other than observations from in this study are derived through correlation with stage boundaries, biostratigraphic zonal boundaries and/or magnetostratigraphy that are part of the Gradstein et al. (2005) scale. A later time scale is now available (Ogg et al. 2008); we did not use this time scale because it is not formally published, does not fully provide data sources, and appears to have internal inconsistencies. The "NN" and "NP" zones referred to below were defined by Martini (1971).

LAD of Pseudoemiliania lacunosa The LAD of 0.44 Ma was astronomically calibrated by Lourens et al. (2005) from the Ceara Rise, western equatorial Atlantic. This event marks the top of Zone NN 19.

LAD of Pseudoemiliania ovata The LAD of $0.44 \mathrm{Ma}$ is the same as that of Pseudoemiliania lacunosa.

LAD of Helicosphaera sellii The LAD of 1.26 Ma was astronomically calibrated by Lourens et al. (2005) in the eastern Mediterranean.

LAD of Calcidiscus macintyrei The LAD of $1.61 \mathrm{Ma}$ was astronomically calibrated by Lourens et al. (2005) on the Ceara Rise, western equatorial Atlantic.

LAD of Discoaster spp. The LAD of Discoaster brouweri (the youngest surviving species of Discoaster) is $1.93 \mathrm{Ma}$, as astronomically calibrated by Lourens et al. (2005) on the Ceara Rise, western equatorial Atlantic.

LAD of Discoaster pentaradiatus The LAD of 2.39 Ma was astronomically calibrated by Lourens et al. (2005) on the Ceara Rise, western equatorial Atlantic. This event marks the top of nannofossil Zone NN17.

LAD of Reticulofenestra pseudoumbilica The LAD of 3.70 Ma was astronomically calibrated by Lourens et al. (2005) on the Ceara Rise, western equatorial Atlantic. This event defines the top of nannofossil zone NN 15.

LAD of Sphenolithus abies The LAD of this species was recorded by Young (1998) as occurring at approximately the same age as the LAD of Reticulofenestra pseudoumbilica (3.70 Ma).

FAD of Pseudoemiliania spp. The FAD of Pseudoemiliania spp. was recorded by Young (1998) as slightly older than the
LAD of Reticulofenestra pseudoumbilica. It is here assigned an age of $3.80 \mathrm{Ma}$.

LAD of Amaurolithus delicatus The LAD of $4.00 \mathrm{Ma}$ is determined from Young (1998) and converted to the Gradstein et al. (2005) time scale.

LAD of Discoaster quinqueramus The LAD of $5.58 \mathrm{Ma}$ was astronomically calibrated by Lourens et al. (2005) on the Ceara Rise, western equatorial Atlantic. The range of this species defines nannofossil zone NN 11.

LAD of Reticulofenestra rotaria The LAD of 5.99 Ma was astronomically calibrated by Lourens et al. (2005) in the eastern Mediterranean.

LAD of Discoaster berggrenii The LAD of 6.66 Ma is determined from Young (1998) and converted to the Gradstein et al. (2005) time scale.

LAD of Discoaster loeblichii The LAD of 6.66 Ma is determined from Young (1998) and converted to the Gradstein et al. (2005) time scale.

LAD of Minylitha convallis The LAD of 7.84 Ma is determined from Berggren et al. (1995) and converted to the Gradstein et al. (2005) time scale. A slightly older age of 8.68 Ma was astronomically calibrated for this event by Lourens et al. (2005) in the eastern Mediterranean.

FAD of Discoaster berggrenii The FAD of $8.20 \mathrm{Ma}$ is determined from Gradstein et al. (2005, fig. 21.1).

LAD of Discoaster deflandrei The LAD of $10.80 \mathrm{Ma}$ is determined from Young (1998). He placed this event at the base of NN8 (FAD of Catinaster coalitus). The age has been modified here to accord with the time scale of Gradstein et al. (2005).

LAD of Coronocyclus nitescens The LAD of $12.32 \mathrm{Ma}$ is determined from Young (1998), and converted to the Gradstein et al. (2005) time scale.

LAD of Cyclicargolithus floridanus We have adopted an LAD of $13.33 \mathrm{Ma}$ which was astronomically calibrated on the Ceara Rise by Lourens et al. (2005) for this datum. This is also in agreement with Young (1998, fig. 8.3) who tentatively considered it to range into NN7. However, this level is contentious because of the lack of agreement on the circumscription of the species and its rarity in the later part of its range.

LAD of Sphenolithus heteromorphus The LAD of $13.53 \mathrm{Ma}$ was astronomically calibrated by Lourens et al. (2005) on the Ceara Rise, western equatorial Atlantic. This event marks the top of nannofossil zone NN 5.

LAD of Discoaster petaliformis The LAD of 14.00 Ma is de- 
termined from Young (1998) and converted to the Gradstein et al. (2005) time scale.

LAD of Helicosphaera ampliaperta The LAD of $14.91 \mathrm{Ma}$ was astronomically calibrated by Lourens et al. (2005) on the Ceara Rise, western equatorial Atlantic. This event marks the top of nannofossil zone NN 4.

LAD of Sphenolithus belemnos The LAD of $18.00 \mathrm{Ma}$ is from Gradstein et al. (2005, fig 21.1). This event defines the top of nannofossil zone NN 3.

LAD of Triquetrorhabdulus carinatus The LAD of $18.28 \mathrm{Ma}$ was astronomically calibrated by Lourens et al. (2005) on the Ceara Rise, western equatorial Atlantic. This event marks the top of nannofossil zone NN 2.

LAD of Clausicoccus fenestratus The LAD of $22.93 \mathrm{Ma}$ is determined from Young (1998) and modified here to accord with the Gradstein et al. (2005) time scale.

LAD of Reticulofenestra bisecta The LAD of 23.10 Ma equates with the top of nannofossil zone NP 25 (Martini 1971) as included in Luterbacher et al. (2005, fig. 20.1).

LAD of Zygrhablithus bijugatus The LAD of 23.79 Ma is from Berggren et al. (1995), modified here to accord with the time scale of Gradstein et al. (2005).

LAD of Chiasmolithus altus The LAD of $24.80 \mathrm{Ma}$ is determined from Varol (1998), modified here to accord with the time scale of Gradstein et al. (2005).

LAD of Isthmolithus recurvus The $\mathrm{LAD}$ of $31.99 \mathrm{Ma}$ is from Berggren et al. (1995), modified here to accord with the time scale of Gradstein et al. (2005).

LAD of Reticulofenestra umbilica The LAD of $32.40 \mathrm{Ma}$ is from Luterbacher et al. (2005, fig. 20.1). This event marks the top of nannofossil zone NP 22.

LAD of Reticulofenestra samodurovii The LAD of $32.40 \mathrm{Ma}$ is from Luterbacher et al. (2005, fig. 20.1)

LAD of Chiasmolithus oamaruensis The LAD of $32.70 \mathrm{Ma}$ is determined from Perch-Nielsen (1985a).

LAD of Cyclococcolithus formosus The LAD of $33.10 \mathrm{Ma}$ is from Luterbacher et al. (2005, fig. 20.1). This event marks the top of nannofossil zone NP 21.

LAD of Pemma papillata The LAD of $33.88 \mathrm{Ma}$ is determined from Varol (1998), modified here to accord with the time scale of Gradstein et al. (2005).

LAD of Discoaster saipanensis The LAD of 34.40 Ma is from
Hardenbol et al.(1998), modified here to accord with the time scale of Gradstein et al. (2005).

LAD ofDiscoaster barbadiensis The LAD of $34.40 \mathrm{Ma}$ is from Luterbacher et al. (2005, fig. 20.1).

LAD of Reticulofenestra reticulata The LAD of $35.28 \mathrm{Ma}$ is from Berggren et al. (1995), modified here to accord with the time scale of Gradstein et al. (2005).

LAD of Daktylethra punctulata The LAD of $35.98 \mathrm{Ma}$ is determined from Perch-Nielsen (1985a), modified here to accord with the time scale of Gradstein et al. (2005).

FAD of Chiasmolithus oamaruensis The FAD of $36.70 \mathrm{Ma}$ is from Hardenbol et al. (1998), modified here to accord with the time scale of Gradstein et al. (2005). This event marks the base of nannofossil zone NP 18.

LAD of Chiasmolithus grandis The LAD of $36.80 \mathrm{Ma}$ is from Luterbacher et al. (2005, fig. 20.1).

LAD of Sphenolithus furcatolithoides The LAD of $39.35 \mathrm{Ma}$ is determined from Martini and Müller (1986), modified here to accord with the time scale of Gradstein et al. (2005).

LAD of Chiasmolithus solitus The LAD of $39.60 \mathrm{Ma}$ is from Luterbacher et al. (2005, fig. 20.1). This event marks the top of nannofossil zone NP 16.

LAD of Sphenolithus editus The LAD of $39.61 \mathrm{Ma}$ of Sphenolithus spiniger (here grouped with Sphenolithus editus) is determined from Perch-Nielsen (1985a), modified here to accord with the time scale of Gradstein et al. (2005).

LAD of Campylosphaera dela The LAD of 42.12 Ma is determined from Perch-Nielsen (1985a), modified here to accord with the time scale of Gradstein et al. (2005).

LAD of Nannotetrina fulgens The LAD of $42.12 \mathrm{Ma}$ is from Berggren et al. (1995), modified here to accord with the time scale of Gradstein et al. (2005).

LAD of Rhabdosphaera inflata The LAD of $43.51 \mathrm{Ma}$ is determined from Perch-Nielsen (1985a), modified here to accord with the time scale of Gradstein et al. (2005).

LAD of Chiasmolithus gigas The LAD of $43.60 \mathrm{Ma}$ is from Luterbacher et al. (2005, fig. 20.1). The range of this species defines nannofossil sub-zone NP15b.

LAD of Lophodolithus mochloporus The LAD of $44.55 \mathrm{Ma}$ is determined from Perch-Nielsen (1985a), modified here to accord with the time scale of Gradstein et al. (2005).

FAD of Chiasmolithus gigas The FAD of $45.00 \mathrm{Ma}$ is from 
Luterbacher et al. (2005, fig. 20.1). The range of this species defines nannofossil sub-zone NP15b.

LAD of Lophodolithus nascens The LAD of $45.62 \mathrm{Ma}$ is determined from Perch-Nielsen (1985a), modified here to accord with the time scale of Gradstein et al. (2005).

FAD of Nannotetrina fulgens The FAD of $46.60 \mathrm{Ma}$ is from Luterbacher et al. (2005, fig. 20.1). This event defines the base of nannofossil zone NP 15.

LAD of Discoaster lodoensis The LAD of $46.60 \mathrm{Ma}$ is determined from Martini (1971), modified here to accord with the time scale of Gradstein et al. (2005).

LAD of Discoaster kuepperi The LAD of $47.11 \mathrm{Ma}$ is determined from Perch-Nielsen (1985a), modified here to accord with the time scale of Gradstein et al. (2005).

FAD of Rhabdosphaera inflata The FAD of $47.80 \mathrm{Ma}$ is from Luterbacher et al. (2005, fig. 20.1).

LAD of Toweius magnicrassus The LAD of $47.80 \mathrm{Ma}$ is determined from Perch-Nielsen (1985a), modified here to accord with the time scale of Gradstein et al. (2005).

FAD of Discoaster kuepperi The FAD of $52.21 \mathrm{Ma}$ is determined from Perch-Nielsen (1985a), modified here to accord with the time scale of Gradstein et al. (2005).

FAD of Discoaster lodoensis The FAD of $52.60 \mathrm{Ma}$ is from Luterbacher et al. (2005, fig. 20.1); this event defines the base of nannofossil zone NP 12.

LAD of Discoaster multiradiatus The LAD of $53.40 \mathrm{Ma}$ is determined from Perch-Nielsen (1985a), modified here to accord with the time scale of Gradstein et al. (2005).

LAD of Toweius eminens The LAD of 55.10 Ma is determined from Perch-Nielsen (1985a), modified here to accord with the time scale of Gradstein et al. (2005).

LAD of Fasciculithus involutus The LAD of 55.21 Ma is determined from Perch-Nielsen (1985a), modified here to accord with the time scale of Gradstein et al. (2005).

LAD of Prinsius martinii The LAD of $55.66 \mathrm{Ma}$ is based on unpublished observations by one of us (JAC).

LAD of Toweius tovae The LAD of $55.99 \mathrm{Ma}$ is determined from Perch-Nielsen (1985a), modified here to accord with the time scale of Gradstein et al. (2005).

LAD of Fasciculithus tympaniformis The LAD of 56.02 Ma is from Berggren et al. (1995), modified here to accord with the time scale of Gradstein et al. (2005).
LAD of Heliolithus kleinpellii The LAD of $56.55 \mathrm{Ma}$ is determined from Perch-Nielsen (1985a), modified here to accord with the time scale of Gradstein et al. (2005).

FAD of Toweius tovae The FAD of $56.77 \mathrm{Ma}$ is determined from Perch-Nielsen (1985a), modified here to accord with the time scale of Gradstein et al. (2005).

FAD of Discoaster multiradiatus The FAD of $56.90 \mathrm{Ma}$ is from Luterbacher et al. (2005, fig. 20.1); this event defines the base of nannofossil zone NP9.

LAD of Heliolithus riedelii The LAD of $56.90 \mathrm{Ma}$ is determined from Perch-Nielsen (1985a).

LAD of Fasciculithus janii (sensu lato) The LAD of $59.21 \mathrm{Ma}$ is determined from Perch-Nielsen (1985a), modified here to accord with the time scale of Gradstein et al. (2005).

LAD of Neochiastozygus imbriei The LAD of $60.57 \mathrm{Ma}$ is determined from Perch-Nielsen (1985a), modified here to accord with the time scale of Gradstein et al. (2005).

LAD of Arkhangelskiella cymbiformis The LAD of $65.50 \mathrm{Ma}$ is determined from Perch-Nielsen (1985b), modified here to accord with the time scale of Gradstein et al. (2005).

LAD of Ceratolithoides kamptneri The LAD of $65.50 \mathrm{Ma}$ is determined from Perch-Nielsen (1985b).

LAD of Cribrocorona gallica The $\mathrm{LAD}$ of $65.50 \mathrm{Ma}$ is determined from Perch-Nielsen (1985b), modified here to accord with the time scale of Gradstein et al. (2005).

LAD of Cribrosphaerella daniae The LAD of $65.50 \mathrm{Ma}$ is determined from Perch-Nielsen (1985b), modified here to accord with the time scale of Gradstein et al. (2005).

LAD of Eiffelithus turriseiffelii The LAD of $65.50 \mathrm{Ma}$ is determined from Perch-Nielsen (1985b), modified here to accord with the time scale of Gradstein et al. (2005).

LAD of Kamptnerius magnificus The LAD of $65.50 \mathrm{Ma}$ is determined from Perch-Nielsen (1985b), modified here to accord with the time scale of Gradstein et al. (2005).

LAD of Lithraphidites quadratus The LAD of $65.50 \mathrm{Ma}$ is determined from Perch-Nielsen (1985b), modified here to accord with the time scale of Gradstein et al. (2005).

LAD of Micula spp. of Vekshina (1959) The LAD of $65.50 \mathrm{Ma}$ is from Hardenbol et al. (1998), modified here to accord with the time scale of Gradstein et al. (2005).

LAD of Nephrolithus frequens The LAD of $65.50 \mathrm{Ma}$ is deter- 
mined from Perch-Nielsen (1985b), modified here to accord with the time scale of Gradstein et al. (2005).

FAD of Ceratolithoides kamptneri The FAD of $66.13 \mathrm{Ma}$ is determined from Burnett (1998; Indian Ocean), modified here to accord with the time scale of Gradstein et al. (2005).

FAD of Micula prinsii The FAD of $66.20 \mathrm{Ma}$ is from Ogg et al. (2005, fig 19.1).

FAD of Nephrolithus frequens The FAD of $66.60 \mathrm{Ma}$ is from Ogg et al. (2005, fig 19.1).

FAD of Cribrosphaerella daniae The FAD of $67.82 \mathrm{Ma}$ is from Hardenbol et al. (1998; Boreal), modified here to accord with the time scale of Gradstein et al. (2005).

FAD of Micula murus The FAD of $68.10 \mathrm{Ma}$ is from Ogg et al. (2005, fig 19.1).

FAD of Lithraphidites quadratus The FAD of $68.50 \mathrm{Ma}$ is from Ogg et al. (2005, fig 19.1).

LAD of Reinhardtites levis The LAD of 69.00 Ma is from Ogg et al. (2005, fig 19.1).

LAD of Uniplanarius trifidus The LAD of $70.00 \mathrm{Ma}$ is from Ogg et al. (2005, fig. 19.1, as Quadrum trifidum; Tethys).

LAD of Tranolithus orionatus The LAD of $70.23 \mathrm{Ma}$ is from Ogg et al. (2005, fig 19.1, as Tranolithus phacelosus).

LAD of Broinsonia parca subspecies constricta The LAD of 70.65 Ma is from Hardenbol et al. (1998; Tethys), modified here to accord with the time scale of Gradstein et al. (2005).

LAD of Uniplanarius sissinghii The LAD of $70.97 \mathrm{Ma}$ is from Hardenbol et al. (1998), as Quadrum sissinghii and Quadrum gothicum; Tethys, modified here to accord with the time scale of Gradstein et al. (2005)

LAD of Broinsonia parca subspecies parca The range of 75.10-83.80 Ma is from Ogg et al. (2005, fig 19.1), as A. parcus parcus. This range is substantially older than that reported by Hardenbol et al. (1998).

LAD of Eiffellithus eximius The LAD of $75.60 \mathrm{Ma}$ is from Ogg et al. (2005, fig. 19.1).

LAD of Reinhardtites anthophorus The LAD of $75.60 \mathrm{Ma}$ is from Hardenbol et al. (1998; Boreal), modified here to accord with the time scale of Gradstein et al. (2005).

FAD of Uniplanarius trifidus The FAD 76.40 Ma is from Ogg et al. (2005, fig. 19.1), as Quadrum trifidum; Tethys.
FAD of Uniplanarius sissinghii The FAD of $77.40 \mathrm{Ma}$ is from Ogg et al. (2005, fig. 19.1), as Quadrum sissinghii.

FAD of Ceratolithoides aculeus The FAD of $78.90 \mathrm{Ma}$ is from Ogg et al. (2005, fig. 19.1).

LAD of Eprolithus floralis The LAD of $84.00 \mathrm{Ma}$ is from Ogg et al. (2005, fig. 19.1).

LAD of Lithastrinus septenarius The LAD of 85.17 Ma is from Hardenbol et al. (1998; Tethys), modified here to accord with the time scale of Gradstein et al. (2005).

LAD of Rhagodiscus achlyostaurion The LAD of $87.64 \mathrm{Ma}$ is determined from Burnett (1998), modified here to accord with the time scale of Gradstein et al. (2005).

LAD of Gartnerago theta The LAD of $89.30 \mathrm{Ma}$ is a local event observed in the present study.

LAD of Liliasterites spp. The LAD of 89.30 Ma is determined from Stradner and Steinmetz (1984), modified here to accord with the time scale of Gradstein et al. (2005).

LAD of Radiolithus planus The LAD of $89.30 \mathrm{Ma}$ is determined from Varol (1992), modified here to accord with the time scale of Gradstein et al. (2005).

LAD of Eprolithus apertior The LAD of $90.30 \mathrm{Ma}$ is determined from Burnett (1998), modified here to accord with the time scale of Gradstein et al. (2005).

LAD of Stoverius achylosus The LAD of $90.50 \mathrm{Ma}$ is determined from Burnett (1998), modified here to accord with the time scale of Gradstein et al. (2005).

FAD of Lithastrinus septenarius The FAD of $90.70 \mathrm{Ma}$ is from Hardenbol et al. (1998; Tethys), modified here to accord with the time scale of Gradstein et al. (2005).

FAD of Eiffellithus eximius The FAD of $90.90 \mathrm{Ma}$ is from Ogg et al. (2005, fig. 19.1).

FAD of Eprolithus eptapetalus The FAD of $93.33 \mathrm{Ma}$ is determined from Burnett (1998), modified here to accord with the time scale of Gradstein et al. (2005).

FAD of Eprolithus octopetalus The FAD of $93.45 \mathrm{Ma}$ is determined from Burnett (1998), modified here to accord with the time scale of Gradstein et al. (2005).

FAD of Ahmuellerella octoradiata The FAD of $93.49 \mathrm{Ma}$ is determined from Burnett (1998), modified here to accord with the time scale of Gradstein et al. (2005).

FAD of Quadrum gartneri The FAD of 93.50 Ma is from 
Hardenbol et al. (1998), modified here to accord with the time scale of Gradstein et al. (2005).

LAD of Rhagodiscus asper The $\mathrm{LAD}$ of $93.80 \mathrm{Ma}$ is determined from Burnett (1998), modified here to accord with the time scale of Gradstein et al. (2005).

LAD of Axopodorhabdus albianus The LAD of $93.80 \mathrm{Ma}$ is determined from Burnett (1998), modified here to accord with the time scale of Gradstein et al. (2005).

LAD of Gartnerago nanum The LAD of 94.16 Ma is determined from Burnett (1998), modified here to accord with the time scale of Gradstein et al. (2005).

LAD of Corollithion kennedyi The LAD of $94.46 \mathrm{Ma}$ is from Hardenbol et al (1998; Tethys), modified here to accord with the time scale of Gradstein et al. (2005).

LAD of Owenia hillii The LAD of $94.62 \mathrm{Ma}$ is determined from Burnett (1998), modified here to accord with the time scale of Gradstein et al. (2005).

LAD of Microstaurus chiastius The LAD of $94.69 \mathrm{Ma}$ is from Hardenbol et al. (1998; Tethys), modified here to accord with the time scale of Gradstein et al. (2005).

LAD of Watznaueria britannica The LAD of $97.50 \mathrm{Ma}$ is determined from Burnett (1998), modified here to accord with the time scale of Gradstein et al. (2005).

\section{Palynomorphs}

LAD of Achomosphaera andalousiensis This species is extant in northern mid-latitudes, as reported in Williams et al. (2004).

LAD of Operculodinium centrocarpum This species is extant in northern mid-latitudes, as reported in Williams et al. (1999).

LAD of Spiniferites ramosus This species is extant in northern mid-latitudes, as reported in Williams et al. (1999).

LAD of Hystrichokolpoma rigaudiae The LAD of $0.50 \mathrm{Ma}$ is based on its LAD as reported in Williams et al. (1999), in which the age provided accords also with the time scale of Gradstein et al. (2005).

LAD of Batiacasphaera micropapillata The LAD of $2.00 \mathrm{Ma}$ is based on its LAD in Shelburne G-29, where this horizon is intermediate between the LADs of the nannofossils Calcidiscus macintyrei (1.61 Ma) and Discoaster pentaradiatus (2.39 Ma).

LAD of Barssidinium graminosum The LAD of $3.90 \mathrm{Ma}$ is based on its LAD in Shubenacadie H-100, where this horizon is intermediate between the LADs of the nannofossils Sphenolithus abies (3.70 Ma) and Amaurolithus delicatus (4.00 $\mathrm{Ma})$.

LAD of Barssidinium pliocenicum The LAD of $3.90 \mathrm{Ma}$ is based on the general coincidence of this horizon with the LAD of Barssidinium graminosum.

LAD of Cousteaudinium aubryae The LAD of $4.80 \mathrm{Ma}$ is based on its LAD in Shubenacadie H-100, where this horizon is intermediate between the LADs of the nannofossils Amaurolithus delicatus (4.00 Ma) and Discoaster quinqueramus (5.58 Ma).

LAD of Reticulatosphaera actinocoronata The LAD of 4.80 $\mathrm{Ma}$ is based on its LAD in Shubenacadie H-100, where this horizon is intermediate between the LADs of the nannofossils Amaurolithus delicatus (4.00 Ma) and Discoaster quinqueramus (5.58 Ma).

LAD of Spiniferites ovatus The LAD of $4.80 \mathrm{Ma}$ is based on its LAD in Hesper I-52, where this horizon coincides with the LAD of Cousteaudinium aubryae.

LAD of Cleistosphaeridium ancyreum The LAD of $6.66 \mathrm{Ma}$ for Cleistosphaeridium ancyreum and Cleistosphaeridium diversispinosum is based on its co-occurrence in Shubenacadie $\mathrm{H}-100$ with the LAD of the nannofossil Discoaster berggrenii (6.66 Ma).

LAD of Cleistosphaeridium diversispinosum LAD of 6.66 Ma. See discussion under Cleistosphaeridium ancyreum.

LAD of Hystrichosphaeropsis obscura The LAD of 7.51 Ma is based on its LAD as reported in Williams et al. (1999), modified here to accord with the time scale of Gradstein et al. (2005).

LAD of Labyrinthodinium truncatum The LAD of $8.05 \mathrm{Ma}$ is based on known occurrences reported in the literature (e.g. Williams et al. 1999), modified here to accord with the time scale of Gradstein et al. (2005).

LAD of Minisphaeridium latirictum The LAD of $8.05 \mathrm{Ma}$ is based on its LAD in Onondaga E-84, where this horizon coincides with the LAD of Labyrinthodinium truncatum.

LAD of Palaeocystodinium golzowense The LAD of $8.05 \mathrm{Ma}$ is based on its LAD in Onondaga E-84, where this horizon coincides with the LAD of Labyrinthodinium truncatum.

LAD of Mendicodinium? robustum The LAD of $8.47 \mathrm{Ma}$ is based on its LAD as reported in Williams et al. (1999), modified here to accord with the time scale of Gradstein et al. (2005).

LAD of Pentadinium laticinctum The LAD of $8.79 \mathrm{Ma}$ is 
based on its LAD as reported in Williams et al. (1999), modified here to accord with the time scale of Gradstein et al. 2005).

LAD of Dapsilidinium pseudocolligerum The LAD of 11.61 Ma is based on its order of relative occurrence in Shubenacadie $\mathrm{H}-100$ and other wells, especially with regard to Palaeocystodinium golzowense.

LAD of Apteodinium australiense The LAD of $12.21 \mathrm{Ma}$ is based on its LAD as reported in Williams et al. (1999), modified here to accord with the time scale of Gradstein et al. (2005).

LAD of Achomosphaera alcicornu The LAD of $12.63 \mathrm{Ma}$ is based on the LAD for northern mid-latitude occurrences as reported in Williams et al.(2004), modified here to accord with the time scale of Gradstein et al. (2005).

LAD of Distatodinium paradoxum The LAD of $12.97 \mathrm{Ma}$ is based on its LAD as reported in Williams et al. (1999), modified here to accord with the time scale of Gradstein et al. (2005).

LAD of Apteodinium spiridoides The LAD of $13.35 \mathrm{Ma}$ is based on its LAD as reported in Williams et al. (1999), modified here to accord with the time scale of Gradstein et al. (2005).

LAD of Oligokolpoma tubulus The LAD of 13.50 Ma is based on its LAD in Wenonah J-75, where this horizon is intermediate between the LADs of Distatodinium paradoxum (12.97 Ma) and Cordosphaeridium cantharellus (14.00 Ma).

LAD of Cordosphaeridium cantharellus The LAD of 14.00 Ma is based on its LAD in Shubenacadie H-100, where this horizon is intermediate between the LADs of the nannofossils Sphenolithus heteromorphus (13.53 Ma) and Helicosphaera ampliapeta (14.91 Ma); the bias towards the latter LAD takes into account that Williams et al. (2004) placed the LAD (northern mid-latitudes) of Cordosphaeridium cantharellus at $17.66 \mathrm{Ma}$, modified here to accord with the time scale of Gradstein et al. (2005).

LAD of Exochosphaeridium insigne The LAD of $14.00 \mathrm{Ma}$ is based on its LAD in Wenonah J-75, where this horizon coincides with the LAD of Cordosphaeridium cantharellus.

Common LAD of Mendicodinium? robustum The common occurrence LAD of $14.00 \mathrm{Ma}$ is based on its LAD in Shubenacadie $\mathrm{H}-100$, where this horizon occurs just below the LAD of the nannofossil Sphenolithus heteromorphus (13.53 Ma).

LAD of Unipontidinium aquaeductus The LAD of $14.00 \mathrm{Ma}$ is based on its LAD in Wenonah J-75, where this horizon coincides with the LAD of Cordosphaeridium cantharellus.

LAD of Cerebrocysta waipawaensis The LAD of $19.00 \mathrm{Ma}$ is based on its LAD in Wenonah J-75, where this horizon is inter- mediate between the LADs of Cordosphaeridium cantharellus (14.00 Ma) and Chiropteridium galea (21.90 Ma). In Wenonah $\mathrm{J}-75$, the LAD of this species occurs just below that of the nannofossil Triquetrorhabdulus carinatus (18.28 Ma).

LAD of Chiropteridium galea The LAD of $21.90 \mathrm{Ma}$ is based on the LAD for northern mid-latitude occurrences of this species as reported in Williams et al. (2004), modified here to accord with the time scale of Gradstein et al. (2005).

LAD of Homotryblium plectilum The LAD of $21.90 \mathrm{Ma}$ is based on its co-occurrence with Chiropteridium galea, for example in Wenonah J-75.

LAD of Membranophoridium aspinatum The LAD of 21.90 $\mathrm{Ma}$ is based on its co-occurrence with Chiropteridium galea, for example in Wenonah J-75.

LAD of Pentadinium sabulum The LAD of $21.90 \mathrm{Ma}$ is based on its co-occurrence with Chiropteridium galea, for example in Hesper I-52.

LAD of Hystrichokolpoma truncatum The LAD of $22.83 \mathrm{Ma}$ is based on its LAD as reported in Williams et al. (1999). This horizon also appears to be closely associated with the LAD of the nannofossil Reticulofenestra bisecta (23.10 Ma).

LAD of Deflandrea phosphoritica The LAD of $23.50 \mathrm{Ma}$ is based on the occurrence of this horizon in Wenonah J-75 below the LAD of Chiropteridium galea $(21.90 \mathrm{Ma})$ and just below that of the nannofossil Clausicoccus fenestratus (22.93 Ma).

LAD of Wetzeliella symmetrica The LAD of 23.50 Ma is based on its LAD in Wenonah J-75, where this horizon is intermediate between the LADs of the nannofossils Zygrhablithus bijugatus $(23.79 \mathrm{Ma})$ and Reticulofenestra bisecta $(23.10 \mathrm{Ma})$.

LAD of Wetzeliella articulata The LAD of $26.23 \mathrm{Ma}$ is based on the general coincidence of this horizon with the LAD for Wetzeliella gochtii.

LAD of Wetzeliella gochtii The LAD of $26.23 \mathrm{Ma}$ is based on its LAD as reported in Williams et al. (1999), modified here to accord with the time scale of Gradstein et al. (2005).

LAD of Thalassiphora pelagica The LAD of 26.50 Ma is based on its LAD in Powell (1986), who investigated Tethyan dinocyst events in Italy and indicated this event to be within nannofossil zone NP25. This correlation equates approximately with an age of 26.50 Ma in the Gradstein et al. (2005) time scale.

LAD of Heteraulacacysta pustulata The LAD of $30.20 \mathrm{Ma}$ is based on the occurrence in Onondaga E-84 of this horizon above the LAD of Licracysta corymbus (30.52 Ma), which in turn is above the LAD of Eocladopyxis peniculata (30.73 Ma). 
LAD of Palaeocystodinium obesum The LAD of 30.20 is based on its LAD in Onondaga E-84, where this horizon is closely similar to the LAD of Heteraulacacysta pustulata.

LAD of Wetzeliella simplex The LAD of $30.41 \mathrm{Ma}$ is based on the LAD for the closely related species Wetzeliella spinula as reported in Williams et al. (1999), modified here to accord with the time scale of Gradstein et al. (2005).

LAD of Licracysta corymbus The LAD of $30.52 \mathrm{Ma}$ is based on its LAD in Onondaga E-84, where this horizon occurs above the LAD of Eocladopyxis peniculata (30.73 Ma).

LAD of Eocladopyxis peniculata The LAD of $30.73 \mathrm{Ma}$ is based on its LAD as reported in Williams et al.(1999), modified here to accord with the time scale of Gradstein et al. (2005).

LAD of Phthanoperidinium coreoides The LAD of 30.73 Ma is based on the LAD as reported in Williams et al. (1999), modified here to accord with the time scale of Gradstein et al. (2005) for Phthanoperidinium comatum, under which name this species has commonly been included.

LAD of Cordosphaeridium fibrospinosum The LAD of 31.15 Ma is based on its LAD as reported in Williams et al. (1999), modified here to accord with the time scale of Gradstein et al. (2005). This species is very rare on the Scotian Margin in the upper parts of its literature-reported range, but is sometimes common, and can thus be a stratigraphic indicator, in the Late Paleocene.

LAD of Hystrichokolpoma grimmertingenense The LAD of $33.05 \mathrm{Ma}$ is based on its LAD in Onondaga E-84 immediately above that of Rhombodinium perforatum (33.10 Ma).

LAD of Palaeocystodinium teespinosum The LAD of 33.05 Ma is based on its LAD in Onondaga E-84, where this horizon is immediately above the LAD of Rhombodinium perforatum (33.10 Ma).

LAD of Rhombodinium perforatum The LAD of $33.10 \mathrm{Ma}$ is based on its LAD as reported in Williams et al. (1999), modified here to accord with the time scale of Gradstein et al. (2005).

LAD of Lentinia serrata The LAD of 33.69 Ma is based on its LAD reported in Williams et al.(1999), modified here to accord with the time scale of Gradstein et al. (2005).

LAD of Glaphyrocysta extensa The LAD of $35.40 \mathrm{Ma}$ is based on its LAD in Sauk A-57 (unpublished observations), where this horizon coincides with the LAD of Schematophora speciosa.

LAD of Glaphyrocysta exuberans The LAD of $35.40 \mathrm{Ma}$ is based on its LAD in Sauk A-57 (unpublished observations), where this horizon coincides with the LAD of Schematophora speciosa.
LAD of Glaphyrocysta retiintexta The LAD of $35.40 \mathrm{Ma}$ is based on its LAD in Sauk A-57 (unpublished observations), where this horizon coincides with the LAD of Schematophora speciosa.

LAD of Schematophora speciosa The LAD of $35.40 \mathrm{Ma}$ is based on its LAD as reported in Williams et al.(1999), modified here to accord with the time scale of Gradstein et al. (2005).

LAD of Talladinium clathratum Based on observations from the Scotian Margin, notably Shubenacadie H-100, during this and earlier studies, the LAD of this species appears to conform with the LAD for Charlesdowniea coleothrypta, given in Williams et al. (1999), modified here to accord with the time scale of Gradstein et al. (2005) as $37.45 \mathrm{Ma}$. According to Williams, Damassa, Fensome and Guerstein in Fensome et al. (in press), Talladinium clathratum is restricted to forms with a soleiform archeopyle, but literature records of both Charlesdowniea coleothrypta and Talladinium clathratum (at species level traditionally separated on the extent of the ectophragm, a feature not now emphasized) would both include forms with a soleiform archeopyle.

LAD of Adnatosphaeridium vittatum The LAD of $37.70 \mathrm{Ma}$ is based on its LAD in Shelburne G-29, where this horizon is just below the LAD of the nannofossil Chiasmolithus grandis (36.80 Ma).

Frequent LAD of Adnatosphaeridium vittatum The frequent $\mathrm{LAD}$ at $42.74 \mathrm{Ma}$ is based on this LAD in Shubenacadie H100 , where this horizon coincides with the LAD of Diphyes colligerum.

LAD of Diphyes colligerum The LAD of $42.74 \mathrm{Ma}$ is based on its LAD in Shelburne G-29, where this horizon is just below the LAD of the nannofossil Campylosphaera dela (42.12 Ma).

LAD of Glaphyrocysta divaricata The LAD of $43.81 \mathrm{Ma}$ is based on its LAD as reported in Williams et al. (1999), modified here to accord with the time scale of Gradstein et al. (2005).

LAD of Diphyes ficusoides The LAD of $44.55 \mathrm{Ma}$ is based on its LAD in Shelburne G-29, where this horizon coincides with the LAD of the nannofossil Lophodolithus mochloporus. Williams et al. (1999) gave the LAD of Diphyes ficusoides as $44.55 \mathrm{Ma}$, modified here to accord with the time scale of Gradstein et al. (2005).

LAD of Homotryblium tenuispinosum The LAD of $45.00 \mathrm{Ma}$ is based on its LAD in Shelburne G-29, where this horizon is intermediate between horizons with the respective LADs of Diphyes ficusoides (44.55 Ma) and Deflandrea eocenica (45.50 $\mathrm{Ma})$.

LAD of Deflandrea eocenica The LAD of $45.50 \mathrm{Ma}$ is based on its LAD in Shelburne G-29, where this horizon is intermediate 
between the LAD of the nannofossil Lophodolithus mochloporus (44.55 Ma) and the FAD (based on conventional core) of the nannofossil Nannotetrina fulgens (46.60 Ma).

LAD of Hystrichosphaeridium tubiferum The LAD of 45.94 Ma is based on its LAD as reported in Williams et al. (1999), modified here to accord with the time scale of Gradstein et al. (2005).

LAD of Rottnestia borussica The LAD of 45.94 Ma is based on its LAD in Shubenacadie H-100, where this horizon is intermediate between the LADs of the nannofossils Lophodolithus mochloporus (44.55 Ma) and Discoaster kuepperi (47.11 Ma).

LAD of Cordosphaeridium gracile The LAD of $46.00 \mathrm{Ma}$ is based on its LAD in Shubenacadie H-100, where this horizon is below the LAD of the nannofossil Lophodolithus nascens (45.62 $\mathrm{Ma}$ ) and its LAD in Shelburne G-29, where this horizon is just above the FAD (based on conventional core) of the nannofossil Nannotetrina fulgens $(46.60 \mathrm{Ma})$.

Frequent LAD of Achilleodinium biformoides The frequent $\mathrm{LAD}$ at $46.60 \mathrm{Ma}$ is based on evidence from Onondaga E-84, where this horizon coincides with the LADs of Areoligera circumsenonensis and Areoligera gippingensis.

LAD of Areoligera circumsenonensis The LAD of $46.60 \mathrm{Ma}$ is based on its LAD in Shelburne G-29, where this horizon coincides with the FAD (based on conventional core) of the nannofossil Nannotetrina fulgens $(46.60 \mathrm{Ma})$.

LAD of Axiodinium prearticulatum The LAD of $46.60 \mathrm{Ma}$ is based on its LAD in a conventional core in Shubenacadie H-100, where this horizon coincides with the LADs of Areoligera circumsenonensis, Areoligera gippingensis and Cordosphaeridium delimurum.

LAD of Areoligera gippingensis The LAD of $46.60 \mathrm{Ma}$ is based on its LAD in Shelburne G-29, where this horizon coincides with the FAD (based on conventional core) of the nannofossil Nannotetrina fulgens (46.60 Ma).

LAD of Cordosphaeridium delimurum The LAD of 46.60 Ma is based on its LAD in Onondaga E-84, where this horizon coincides with the LAD of Areoligera circumsenonensis.

LAD of Wetzeliella caviarticulata The LAD of $46.60 \mathrm{Ma}$ is based on its LAD in Onondaga E-84, where this horizon coincides with the "frequent" LAD for Achilleodinium biformoides.

LAD of Hafniasphaera delicata The LAD of 50.09 Ma is provisional and based on the general relationship of its LAD in the general sequence of LADs for other dinocysts and foraminifera, especially in Onondaga E-84.
LAD of Cerodinium glabrum The LAD of $54.76 \mathrm{Ma}$ is based on its LAD in Shelburne G-29, where this horizon coincides with the LAD of Cerodinium speciosum.

LAD of Cerodinium speciosum The LAD of $54.76 \mathrm{Ma}$ is based on its LAD as reported in Williams et al. (1999), modified here to accord with the time scale of Gradstein et al. (2005).

Abundant LAD Apectodinium homomorphum The abundant LAD of Apectodinium homomorphum at $55.80 \mathrm{Ma}$ is based on the establishment of this horizon at the Paleocene-Eocene Thermal Maximum (PETM) event by Crouch at al. (2001). Crouch et al. (2001) referred to the "Late Paleocene Thermal Maximum" but the Paleocene-Eocene boundary was subsequently redefined to coincide with this event, thus becoming the PETM; see Gradstein et al. (2005.)

Common LAD of Areoligera gippingensis The common LAD of $57.86 \mathrm{Ma}$ is based on general relationships with other dinocyst events on the Scotian Margin and comparison with North Sea occurrences, notably as recorded in Powell et al.(1996). On the Scotian Margin and elsewhere in offshore eastern Canada, abundances of the Areoligera gippingensis/Glaphyrocysta divaricata "complex" are commonly characteristic of the later Paleocene. These eastern Canadian occurrences probably equate with the "acmes" of Areoligera senonensis/Areoligera gippingensis reported by Powell et al. (1996, fig. 14) in the early Thanetian, in fairly close association with Alisocysta margarita (LAD: $58.01 \mathrm{Ma}$ - modified here to accord with the time scale of Gradstein et al. 2005 - in Williams et al. 1999). The difference in nomenclature between Canadian offshore and North Sea records is thus probably a result of differences in taxonomic understanding and species designations.

Common LAD of Glaphyrocysta divaricata The common $\mathrm{LAD}$ at $57.86 \mathrm{Ma}$ is based on the general coincidence of this horizon with the LAD for common occurrence of Areoligera gippingensis, which see for further discussion.

LAD of Spinidinium densispinatum The LAD of $60.00 \mathrm{Ma}$ is based on its LADs in Shubenacadie H-100 and Hesper I52 , in both of which this horizon coincides with the LAD for Palaeocystodinium bulliforme.

LAD of Palaeocystodinium bulliforme The LAD of 60.00 Ma is based on its LAD in Shubenacadie H-100, where this horizon is intermediate between the LADs of the nannofossils Fasciculithus jainii (59.21 Ma) and Neochiastozygus imbriei (60.57 Ma).

LAD of Palaeoperidinium pyrophorum The LAD of $60.00 \mathrm{Ma}$ is based on its LAD in Shubenacadie H-100, where this horizon is intermediate the LADs of the nannofossils Fasciculithusjainii (59.21 Ma) and Neochiastozygus imbriei (60.57 Ma).

LAD of Elytrocysta druggii The LAD of $60.83 \mathrm{Ma}$ is based on 
its LAD as reported in Williams et al. (1999), modified here to accord with the time scale of Gradstein et al. (2005).

LAD of Cerodinium diebelii The $\mathrm{LAD}$ of $61.05 \mathrm{Ma}$ is based on its LAD in Demascota G-32, where this horizon coincides with the LAD of Damassadinium californicum.

LAD of Damassadinium californicum The LAD of $61.05 \mathrm{Ma}$ is based on the LAD for northern mid-latitude occurrences for this species as reported in Williams et al. (2004), modified here to accord with the time scale of Gradstein et al. (2005).

LAD of Disphaerogena carposphaeropsis The LAD of 61.05 Ma is based on its LAD in Shubenacadie H-100, where this horizon is intermediate between the LADs of Palaeoperidinium pyrophorum $(60.00 \mathrm{Ma})$ and Manumiella seelandica (61.60 $\mathrm{Ma})$.

LAD of Manumiella seelandica The LAD of $61.60 \mathrm{Ma}$ is based on its LAD as reported in Williams et al. (1999), modified here to accord with the time scale of Gradstein et al. (2005).

LAD of Alisogymnium euclaense The LAD of $65.50 \mathrm{Ma}$ is based on the $\mathrm{LAD}$ for northern mid-latitude occurrences for this species as reported in Williams et al. (2004), modified here to accord with the time scale of Gradstein et al. (2005).

LAD of Cyclonephelium distinctum The LAD of $65.50 \mathrm{Ma}$ is based on its LAD in Shubenacadie H-100, where this horizon coincides with the LAD of the nannofossil Nephrolithus frequens.

LAD of Dinogymnium acuminatum The LAD of 65.50 Ma is based on the $\mathrm{LAD}$ for northern mid-latitude occurrences for this species as reported in Williams et al.(2004), modified here to accord with the time scale of Gradstein et al. (2005).

LAD of Isabelidinium cooksoniae The LAD of $65.50 \mathrm{Ma}$ is based on the LAD of Isabelidinium belfastense (a junior synonym of Isabelidinium cooksoniae according to Fensome et al. in press) as reported in Williams et al. (1999), modified here to accord with the time scale of Gradstein et al. (2005). This horizon also occurs just above the FAD (based on conventional core) of the nannofossil Ceratolithoides kamptneri (66.13 Ma).

LAD of Isabelidinium glabrum The LAD of $65.50 \mathrm{Ma}$ is based on the general coincidence of this horizon with the LAD for Isabelidinium cooksoniae.

LAD of Palynodinium grallator The LAD of $65.50 \mathrm{Ma}$ is based on its LAD as reported in Williams et al. (1999), modified here to accord with the time scale of Gradstein et al. (2005). This horizon also coincides with the LAD of the nannofossil Nephrolithus frequens in Shubenacadie H-100.
LAD of Pierceites pentagonus The LAD of $65.50 \mathrm{Ma}$ is based on its LAD in Onondaga E-84, where this horizon coincides with the LADs of Alisogymnium and Dinogymnium species.

LAD of Spongodinium delitiense The LAD of $65.50 \mathrm{Ma}$ is based on its LAD in Shubenacadie H-100, where this horizon coincides with the LAD of Palynodinium grallator.

LAD of Tanyosphaeridium xanthiopyxides The LAD of 65.50 Ma is based on its LAD in Shelburne G-29, where this horizon coincides with the LAD of Trithyrodinium evittii; this conclusion also is in accordance with nannofossil records in the same well, which support an age for this event around the latest Maastrichtian.

LAD of Trithyrodinium evittii The LAD of $65.50 \mathrm{Ma}$ is based on its LAD in Shubenacadie H-100, where this horizon coincides with the LAD of Palynodinium grallator.

LAD of Coronifera oceanica The LAD of $66.55 \mathrm{Ma}$ is based on its LAD as reported in Williams et al. (1999), modified here to accord with the time scale of Gradstein et al. (2005).

LAD of Kleithriasphaeridium loffrense The LAD of 68.00 $\mathrm{Ma}$ is based on its LAD in Shubenacadie H-100, where this horizon is above the FAD (based on conventional core) of the nannofossils Micula murus (68.10 Ma) and Lithraphidites quadratus $(68.50 \mathrm{Ma})$. This $\mathrm{LAD}$ is younger than previous determinations and may represent reworked material. However, we consider this species to be the senior synonym of Florentinia aculeata which was originally recorded from the Coniacian to Maastrichtian of Germany (Kirsch 1991).

LAD of Alterbidinium acutulum The LAD of $69.14 \mathrm{Ma}$ is based on its LAD in Demascota G-32, where this horizon is intermediate between the LADs of the nannofossils Reinhardtites levis $(69.00 \mathrm{Ma})$ and Tranolithus orionatus $(70.23 \mathrm{Ma})$.

LAD of Chatangiella tripartita The LAD of 69.22 Ma is based on its LAD as reported in Williams et al. (1999), modified here to accord with the time scale of Gradstein et al. (2005).

LAD of Trichodinium castanea The LAD of $71.70 \mathrm{Ma}$ is based on its LAD in Demascota G-32 and Shelburne G-29, where this horizon coincides with the LAD for Xenascus ceratioides.

LAD of Xenascus ceratioides The $\mathrm{LAD}$ of $71.70 \mathrm{Ma}$ is based on its $\mathrm{LAD}$ for northern hemisphere mid-latitudes as reported in Williams et al. (2004), modified here to accord with the time scale of Gradstein et al. (2005).

LAD of Xenascus perforatus The LAD of $71.70 \mathrm{Ma}$ is based on its LAD in both Demascota G-32 and Shelburne G-29, where this horizon is coincident with the LAD for Xenascus ceratioides. 
LAD of Odontochitina costata The LAD of $72.40 \mathrm{Ma}$ is based on its LAD in Shubenacadie H-100, where this horizon is just below the LAD for Xenascus ceratioides $(71.70 \mathrm{Ma})$.

LAD of Palaeohystrichophora infusorioides The LAD of 73.00 Ma is based on its LAD in Hesper I-52, where this horizon is just below the LAD for Odontochitina costata (72.40 Ma).

LAD of Subtilisphaera perlucida The LAD of $74.50 \mathrm{Ma}$ is based on its LAD in Wenonah J-75, where this horizon is below the LAD for Palaeohystrichophora infusorioides (73.00 $\mathrm{Ma}$ ) and above the LAD for common Palaeohystrichophora infusorioides (78.50 Ma); and in Demascota G-32, where this horizon is above the LAD for common Palaeohystrichophora infusorioides (78.50 Ma).

LAD of Raetiaedinium truncigerum The LAD of $75.78 \mathrm{Ma}$ is based on its LAD as reported in Williams et al. (1999), modified here to accord with the time scale of Gradstein et al. (2005).

Common LAD of Palaeohystrichophora infusorioides The common LAD of 78.50 Ma is based on its LAD in Demascota G-32, where this horizon is just above the LADs of Cingutriletes tyriskos (79.50 Ma) and Callaiosphaeridium asymmetricum (79.80 Ma).

LAD of Cingutriletes tyriskos (miospore) The LAD of 79.50 Ma is based on its LAD in Demascota G-32, where this horizon is below the FAD of the nannofossil Ceratolithoides aculeus (78.90 Ma); and in Shelburne G-29, where this horizon is just above the LAD for Callaiosphaeridium asymmetricum and Canningia reticulata (both $79.80 \mathrm{Ma}$ ).

LAD of Callaiosphaeridium asymmetricum The LAD of $79.80 \mathrm{Ma}$ is based on its LAD in Demascota G-32, where this horizon is below the FAD (based on conventional core) of the nannofossil Ceratolithoides aculeus (78.90 Ma).

LAD of Canningia reticulata The $\mathrm{LAD}$ of $79.80 \mathrm{Ma}$ is based on its LADs in Demascota G-32 and Onondaga E-84, where this horizon coincides with the LAD of Callaiosphaeridium asymmetricum. We follow Clarke and Verdier (1967) and others in taking this species up into the Late Cretaceous, in contrast to the range reported by Williams et al. (1999).

LAD of Impletosphaeridium capitatum The LAD of $79.80 \mathrm{Ma}$ is based on its LAD in Demascota G-32, where this horizon coincides with the LAD of Callaiosphaeridium asymmetricum.

LAD of Surculosphaeridium longifurcatum The LAD of $79.80 \mathrm{Ma}$ is based on its LAD in Demascota G-32, where this horizon coincides with the LAD of Callaiosphaeridium asymmetricum.

LAD of Hystrichosphaeridium bowerbankii The LAD of $81.00 \mathrm{Ma}$ is based on its LAD as reported in Williams et al.
(1999), modified here to accord with the time scale of Gradstein et al. (2005).

LAD of Pervosphaeridium granaciculare The LAD of 82.44 Ma is based on its LAD in Shelburne G-29, where this horizon occurs between the LADs of Callaiosphaeridium asymmetricum (79.80 Ma) and Heterosphaeridium difficile (84.70 Ma).

LAD of Dinopterygium alatum The LAD of $84.10 \mathrm{Ma}$ is based on its LAD as reported in Williams et al. (1999 - in which the age provided accords also with the time scale of Gradstein $e t$ al. 2005).

LAD of Heterosphaeridium difficile The LAD of $84.70 \mathrm{Ma}$ is based on its LAD as reported in Williams et al. (1999 - in which the age provided accords also with the time scale of Gradstein et al. 2005).

LAD of Kleithriasphaeridium perforatum The LAD of 84.70 Ma is based on its LAD in Hesper I-52, where this horizon coincides with the LAD of Heterosphaeridium difficile.

LAD of Odontochitina porifera The LAD of $84.70 \mathrm{Ma}$ is based on its LAD as reported in Williams et al. (1999 - in which the age provided accords also with the time scale of Gradstein $e t$ al. 2005).

LAD of Cyclonephelium brevispinatum The LAD of 85.80 Ma is based on the general coincidence of this horizon with the LAD for Cyclonephelium vannophorum.

LAD of Cyclonephelium vannophorum The $\mathrm{LAD}$ of 85.80 Ma is based on its LAD as reported in Williams et al. (1999 - in which the age provided accords also with the time scale of Gradstein et al. 2005).

LAD of Kiokansium williamsii The LAD of $85.80 \mathrm{Ma}$ is based on its LAD in Shubenacadie H-100, where this horizon coincides with the LAD of Cyclonephelium vannophorum.

LAD of Kleithriasphaeridium cooksoniae The LAD of 85.80 Ma is based on its LAD in Shelburne G-29, where this horizon coincides with the LAD of Cyclonephelium vannophorum.

LAD of Senoniasphaera rotundata The LAD of $85.80 \mathrm{Ma}$ is based on its LAD in Demascota G-32, where this horizon coincides with the LAD of Kiokansium williamsii.

LAD of Chlamydophorella nyei The LAD of 87.11 Ma is based on its LAD in Demascota G-32, where this horizon is just below the LAD of Kleithriasphaeridium cooksoniae (85.80 Ma).

LAD of Sepispinula huguoniotii The LAD of 87.11 Ma is based on its LAD in Hesper I-52, where this horizon is just below the LAD of Kiokansium williamsii (85.80 Ma). 
LAD of Litosphaeridium siphoniphorum The LAD of 92.10 Ma is based on its LAD as reported in Williams et al. (1999), modified here to accord with the time scale of Gradstein $e$ t al. (2005).

LAD of Cicatricosisporites minutaestriatus (miospore) The LAD of 92.33 Ma is based on its LAD in Shelburne G-29, where this horizon is intermediate between the FADs (based on conventional core) of the nannofossils Eifellithus eximius (90.90 $\mathrm{Ma}$ ) and Quadrum gartneri (93.50 Ma).

LAD of Odontochitina rhakodes The LAD of $93.00 \mathrm{Ma}$ is based on its LAD in Shelburne G-29, where this horizon is just below the LAD of the miospore Cicatricosisporites minutaestriatus $(92.33 \mathrm{Ma})$.

LAD of Kiokansium unituberculatum The LAD of 94.06 Ma is based on its LAD in Shelburne G-29, where this horizon is just below the LAD for the nannofossil Rhagodiscus asper $(93.80 \mathrm{Ma})$.

Common LAD of Palaeoperidinium cretaceum The common LAD of 95.76 Ma is based on its LAD in Demascota G-32, where this. horizon is just above the common LAD for Kiokansium williamsii $(96.55 \mathrm{Ma})$.

LAD of Protoellipsodinium spp. The LAD of $95.76 \mathrm{Ma}$ is based on its LAD in Demascota G-32, where this. horizon is just above the common LAD of Kiokansium williamsii (96.55 $\mathrm{Ma})$.

LAD of Afropollis sp. (miospore) The LAD of $96.32 \mathrm{Ma}$ is based on its LAD in Demascota G-32, where this horizon is intermediate between the common LADs of Palaeoperidinium cretaceum (95.76 Ma) and Kiokansium williamsii (96.55 $\mathrm{Ma}$ ). This conclusion is supported by information in Doyle et al. (1982), who indicate a middle Cenomanian LAD for Afropollis.

Frequent LAD of Oligosphaeridium perforatum The frequent LAD of 96.44 Ma is based on its LAD in Demascota G-32, where this horizon is immediately below the LAD of Afropollis sp. (96.32 Ma).

Common LAD of Kiokansium williamsii The common LAD for Kiokansium williamsii at $96.55 \mathrm{Ma}$ is based on the overall LAD for this species as reported in Williams et al. (1999), modified here to accord with the time scale of Gradstein et al. (2005).

LAD of Epelidosphaeridia spinosa The frequent LAD for Epelidosphaeridia spinosa at $96.55 \mathrm{Ma}$ is based on the LAD in Demascota G-32, where this horizon coincides with the common LAD for Kiokansium williamsii.

LAD of Vesperopsis mayii The LAD of $96.55 \mathrm{Ma}$ is based on its LAD in Demascota G-32, where this horizon coincides with the frequent LAD for Epelidosphaeridia spinosa.

Frequent LAD of Palaeohystrichophora palaeoinfusa The frequent LAD of $96.89 \mathrm{Ma}$ is based on its LAD in Demascota G-32, where this horizon is just below the common LADs for Kiokansium williamsii and the frequent LAD for Epelidosphaeridia spinosa (both at $96.55 \mathrm{Ma}$ ).

LAD of Oligosphaeridium albertense The LAD of $98.08 \mathrm{Ma}$ is based on its LAD as reported in Williams et al. (1999), modified here to accord with the time scale of Gradstein et al. (2005).

LAD of Oligosphaeridium totum The LAD of $98.08 \mathrm{Ma}$ is based on its LAD in Demascota G-32, where this horizon coincides with the LAD of Oligosphaeridium albertense.

LAD of Chichaouadinium vestitum The LAD of $99.60 \mathrm{Ma}$ is based on its LAD as reported in Williams et al.(1999), modified here to accord with the time scale of Gradstein et al. (2005).

LAD of Nyktericysta tripenta The LAD of $100.00 \mathrm{Ma}$ is based on its LAD in Demascota G-32, where this horizon is below the base of Chichaouadinium vestitum $99.60 \mathrm{Ma}$.

\section{Foraminifera}

LAD of Martinotiella communis The LAD of $5.33 \mathrm{Ma}$ is based on its frequent association with a regionally widespread assemblage of benthic and planktic foraminifera in wells on the Scotian Margin statistically determined by Gradstein and Agterberg (1982) to be of latest Miocene age.

LAD of Uvigerina peregrina The LAD of 9.7 Ma is based on its frequent association with members of a regionally widespread assemblage of benthic and planktic foraminifera statistically determined by Gradstein and Agterberg (1982) to be of Late Miocene age.

LAD of Melonis barleeanum The LAD of $12.97 \mathrm{Ma}$ is based on its frequent association with members of a regionally widespread association of benthic and planktic foraminifera statistically determined by Gradstein and Agterberg (1982) to be of late Middle to early Late Miocene age.

LAD of Neogloboquadrina continuosa The LAD is here placed with that of Apteodinium spiridoides at $13.35 \mathrm{Ma}$. This species, described by Kennett and Srinivasan (1983) as disappearing in the Late Miocene Zone N16, is often found with members of a regionally widespread association of benthic and planktic foraminifera statistically determined by Gradstein and Agterberg (1982) to be no older than late Middle Miocene on the Scotian Margin.

LAD of Pullenia bulloides The LAD is here placed with that of 
Apteodinium spiridoides at $13.35 \mathrm{Ma}$. This species often occurs with members of a regionally widespread association of benthic and planktic foraminifera statistically determined by Gradstein and Agterberg (1982) to be no older than late Middle Miocene age on the Scotian Margin.

LAD of Globigerina praebulloides The LAD is here placed with that of Cordosphaeridium cantherellus and others at 14.00 Ma. This species, described by Kennett and Srinivasan (1983) as disappearing in the Late Miocene Zone N17B, is part of a regionally widespread association of benthic and planktic foraminifera statistically determined by Gradstein and Agterberg (1982) to be of approximately early Middle Miocene age on the Scotian Margin.

LAD of Catapsydrax dissimilis The LAD is here placed at 16.89 Ma. The global LAD of this species is given as the N6/ N7 boundary by Bolli and Saunders (1985) but its uppermost occurrence is usually coeval with members of a regionally widespread association of benthic and planktic foraminifera statistically determined by Gradstein and Agterberg (1982) to be no older than Early Miocene age on the Scotian Margin.

LAD of Globocassidulina subglobosa, Hoeglundina elegans, Lenticulina americana and Melonis pompilioides The LAD for this group of species is here placed at 16.89 Ma. All of these species are part of or closely associated with Gradstein and Agterberg's (1982) assemblage with Catapsydrax dissimilis.

$\mathrm{LAD}$ of Globoquadrina venezuelana The $\mathrm{LAD}$ of $24.60 \mathrm{Ma}$ is based on its occurrences in Onondaga E-84, Shelburne G-29 and Wenonah J-75, where it occurs between the nannofossils Zygrhablithus bijugatus (LAD at $23.79 \mathrm{Ma}$ ) and Chiasmolithus altus (LAD at 24.80 Ma). Although Bolli and Saunders (1985) described this taxon as surviving through the Miocene in some localities, Gradstein and Agterberg (1982) included it as part of an Oligocene assemblage on the Scotian Margin; the species is nowhere known to extend into the Miocene in this region.

LAD of Acarinina spinuloinflata/densa group The LAD of $42.00 \mathrm{Ma}$ is based on occurrences in Hesper I-52, Onondaga E-84, Shelburne G-29 and Shubenacadie H-100, where it occurs above the nannofossils Campylosphaera dela (LAD at 42.12 $\mathrm{Ma}$ ) and Nannotetrina fulgens (LAD at $42.12 \mathrm{Ma}$ ). This taxon is also a marker for a Middle Eocene assemblage of planktic and benthic species described by Gradstein and Agterberg (1982) from several wells on the Scotian Margin.

LAD of Pseudohastigerina wilcoxensis/micra group The LAD of 42.00 Ma for this group is based on occurrences in Hesper I52, Onondaga E-84, Shelburne G-29 and Wenonah J-75, where it occurs above the nannofossils Campylosphaera dela (LAD at $42.12 \mathrm{Ma}$ ) and Nannotetrina fulgens (LAD at $42.12 \mathrm{Ma}$ ). This taxon also is a marker for a Middle Eocene assemblage of planktic and benthic species described by Gradstein and Agterberg (1982) from several wells on the Scotian Margin.
LAD of Lenticulina whitei The LAD is here placed at 48.60 Ma. In erecting this species, Tjalsma and Lohmann(1983) indicated that it was restricted to the Paleocene, but on the Scotian Margin it is frequently associated with members of an Early Eocene assemblage of planktic and benthic species described by Gradstein and Agterberg (1982).

LAD of Nuttalinella florealis The LAD is here placed at 48.60 Ma. In erecting this species, Tjalsma and Lohmann (1983) indicated that it was restricted to the Paleocene, but on the Scotian Margin it is frequently associated with members of an Early Eocene assemblage of planktic and benthic species described by Gradstein and Agterberg (1982).

LAD of Spiroplectammina spectabilis The LAD is here placed at $48.60 \mathrm{Ma}$. On the Scotian Margin, this species is an important member of an Early Eocene assemblage of planktic and benthic species described by Gradstein and Agterberg (1982).

LAD of Glomospira corona The LAD is here placed at 54.76 $\mathrm{Ma}$, with the dinocyst Cerodinium speciosum (LAD at 54.76 $\mathrm{Ma}$ ). This species is often found in Scotian Margin wells associated with Early Eocene and Paleocene forms from Gradstein and Agterberg's (1982) statistically-derived zonation.

LAD of Spiroplectammina navarroana The LAD is here placed at $54.76 \mathrm{Ma}$,with the dinocyst Cerodinium speciosum (LAD at $54.76 \mathrm{Ma}$ ). This species is often found in Scotian Margin wells associated with Early Eocene and Paleocene forms from Gradstein and Agterberg's (1982) statisticallyderived zonation.

\section{ACKNOWLEDGEMENTS}

We are grateful to Bernie Crilley and Nelly Koziel for technical assistance and to Bill MacMillan for so expertly drafting the well and event charts. Lucy Edwards and Douglas Fils provided information with regard to time scale conversion. We'd like to thank David Piper and Hans Wielens of Geological Survey of Canada (Atlantic) for pre-reviewing this paper, and journaldesignated reviewers Mark Deptuck and Jim Riding, as well as editor Sandra Barr, for helpful comments. This is GSC Contribution number 20070598.

\section{REFERENCES}

Barss, M.S., Bujak, J.P., AND Williams, G.L. 1979. Palynological zonation and correlation of sixty-seven wells, eastern Canada. Geological Survey of Canada, Paper 78-24, 118 p.

Berggren, W. A., Kent, D. V., Swisher, C. C., And Aubry, M.-P. 1995. A revised Cenozoic geochronology and chronostratigraphy. In Geochronology, time scales and global correlation. Edited by W.A. Berggren, D.V. Kent, M.-P. 
Aubry, and J. Hardenbol. SEPM Special Publication 54, pp. 129-212.

Bolli, H.M., AND SAunders, J.B., 1985. Oligocene to Holocene low latitude planktic foraminifera. In Plankton stratigraphy. Edited by H.M. Bolli, J.B. Saunders, and K. Perch-Nielsen. Cambridge University Press, Cambridge, U.K., pp. 155-262.

Bown, P. R. 1998. Calcareous nannofossil biostratigraphy. British Micropalaeontological Society and Chapman \& Hall, London, 315 p.

Bujak, J.P., AND Williams, G.L. 1978. Cretaceous palynostratigraphy of offshore southeastern Canada. Geological Survey of Canada, Bulletin 297, 19 p., 3 pl.

BuRnetT, J. A. 1998. Upper Cretaceous. In Calcareous nannofossil biostratigraphy. Edited by P.R. Bown. British Micropalaeontological Society \& Chapman \& Hall, London, pp. 132-199.

CanT, D.J. (co-ordinator). 1991. Scotian Shelf. Frontier Geoscience Program East Coast Basin Atlas Series. Geological Survey of Canada, Dartmouth, Nova Scotia.

Caron, M. 1985. Cretaceous planktic foraminifera. In Plankton stratigraphy. Edited by H.M. Bolli, J.B. Saunders, and K. Perch-Nielsen. Cambridge University Press, Cambridge, U.K., pp. 17-86.

Clarke, R.F.A., ANd Verdier, J.-P. 1967. An investigation of microplankton assemblages from the Chalk of the Isle of Wight, England. Verhandelingen der Koninklijke Nederlandse Akademie van Wetenschappen, Afdeling Natuurkunde, Eerste Reeks, 24, pp. 1-96, pl. 1-17.

Crouch, E.M., Heilmann-Clausen, C., Brinkhuis, H., Morgans, H.E.G., Rogers, K.M., Egger, H., AND Schmitz, B. 2001. Global dinoflagellate event associated with the late Paleocene thermal maximum. Geology, 29, pp. 315-318.

Deptuck, M., MacRae, R.A., Shimeld, J., Williams, G.L., And Fensome, R.A. 2003. Revised Upper Cretaceous and lower Paleogene lithostratigraphy and depositional history of the Jeanne d'Arc Basin, offshore Newfoundland, Canada. American Association of Petroleum Geologists Bulletin, 87, pp. 1459-1483.

Doeven, P. H. 1983. Cretaceous nannofossil stratigraphy and paleoecology of the Canadian Atlantic margin. Geological Survey of Canada Bulletin 356, pp. 1-70.

Doyle, J.A., Jardiné, S., ANd DoEREnKamp, A. 1982. Afropollis, a new genus of early angiosperm pollen, with notes on the Cretaceous palynostratigraphy and paleoenvironments of northern Gondwana. Bulletin des Centres de recherche et exploration-production, Elf-Aquitaine, 6, pp. 39-117.

DyвKJAER, K. 2004. Morphological and abundance variations in Homotryblium-cyst assemblages related to depositional environments; uppermost Oligocene-Lower Miocene, Jylland, Denmark. Palaeogeography, Palaeoclimatology, Palaeoecology, 206, pp. 41-58, pl. 1-2.

Fensome, R.A. 2000. Palynological analysis of Shell et al. Shubenacadie H-100 well, Scotian Slope. Report no. MRGPAL.2-2000RAF, 7 p., 1 chart.
Fensome, R.A. 2001. Palynological analysis of Shell Onondaga E-84 well, Scotian Shelf. Marine Resources Geology Internal Report no. M.RES.G.-PAL.10-2001RAF, 10 p., 1 chart.

Fensome, R.A. 2002. Palynological analysis of Shell Demascota G-32 well, Scotian Shelf. Marine Resources Geology Internal Report no. MRG.-PAL.2-2002RAF, 7 p., 2 charts.

Fensome, R.A. 2003a. Palynological analysis of Petro-Canada et al. Shelburne G-29 well, Scotian Slope. Marine Resources Geology Internal Report no. MRG-PAL.1-2003RAF, 9 p., 1 chart.

Fensome, R.A. 2003b. Palynological analysis of Petro-CanadaShell Wenonah J-75 well, Scotian Shelf. Marine Resources Geology Internal Report no. MRG.-PAL.5-2003RAF, 9 p., 1 chart.

Fensome, R.A. 2003c. Palynological analysis of Petro-CanadaMobil Hesper I-52 well, Scotian Shelf. Marine Resources Geology Internal Report no.MRG.-PAL.4-2003 RAF, 8 p., 1 chart.

Fensome, R.A., Williams, G.L., and MacRae, R.A. In press. Late Cretaceous and Cenozoic fossil dinoflagellates and other palynomorphs from the Scotian Margin, offshore eastern Canada. Journal of Systematic Palaeontology.

Gradstein, F.M., ANd Agterberg, F.P. 1982. Models of Cenozoic foraminiferal stratigraphy - northwestern Atlantic margin. In Quantitative stratigraphic correlation. Edited by J.M. Cubitt and R.A. Reyment. John Wiley and Sons, Limited, Chichester, U.K., pp. 119-174.

Gradstein, F., OgG, J., And Smith, A.G. 2005. A geologic time scale 2004. Cambridge University Press, Cambridge, 589 pp. (Cover date 2004, issue date 2005).

Hardenbol, J., Thierry, J., Farley, M. B., Jacquin, T., de Graciansky, P.-C., ANd Vail, P. R. 1998. Mesozoic and Cenozoic sequence chronostratigraphic framework of European basins. In Mesozoic and Cenozoic sequence stratigraphy of European basins. Edited by P.-C. de Graciansky et al. SEPM Special Publication 60, pp. 3-13.

HARDY, I.A. 1975. Lithostratigraphy of the Banquereau Formation of the Scotian Shelf. In Offshore geology of eastern Canada. Edited by W.J.M. van der Linden and J.A. Wade. Geological Survey of Canada Paper 74-30, pp. 163-174.

JANSA, L.F., AND WADE, J.A. 1975. Geology of the continental margin off Nova Scotia and Newfoundland. In Offshore geology of eastern Canada. Edited by W.J.M. van der Linden and J.A. Wade. Geological Survey of Canada Paper 74-30, pp. 51-105.

Kennett, J.P., And SRInivasan, M.S. 1983. Neogene planktic foraminifera - a phylogenetic atlas. Hutchinson Ross Publishing Company, Stroudsburg, Pennsylvania, 265 p.

KIRSCH, K.-H. 1991. Dinoflagellatenzysten aus der Oberkreide des Helvetikums und Nordultrahelvetikums von Oberbayern. Münchner Geowissenschaftliche Abhandlungen, Reihe A, Geologie und Paläontologie, 22, pp. 1-306, pl. 1-43.

Lourens, L., Hilgen, F., Shackleton, N. J., Laskar, J., And Wilson, D. 2005. The Neogene Period. In A geologic time scale 2004. Edited by F.M. Gradstein, J.G. Ogg, and 
A.G. Smith. Cambridge University Press, Cambridge, pp. 409-440.

Luterbacher, H. P., Ali, J. R., Brinkhuis, H., Gradstein, F. M., Hooker, J. J., Monechi, S., OGg, J. G., Powell, J., Röhl, U., Sanfilippo, A., ANd Schmitz, B. 2005. The Paleogene Period. In A geologic time scale 2004. Edited by F.M. Gradstein, J.G. Ogg, and A.G. Smith. Cambridge University Press, Cambridge, pp. 384-408.

MacLean, B.C., ANd Wade, J.A. 1993. East Coast Basin Atlas Series: seismic markers and stratigraphic picks in Scotian Basin wells. Geological Survey of Canada, Energy, Mines and Resources Canada, $276 \mathrm{p}$.

MacRae, R.A., Shimeld, J., Fensome, R.A., and Thomas, F. 2003. Paleogeography and sediment supply on the Scotian Margin in the Upper Cretaceous and Cenozoic - implications for hydrocarbon prospects. Geological Society of America Northeastern Section, 38th Annual Meeting, Abstracts with Program, p. 16.

Martini, E. 1971. Standard Tertiary and Quaternary calcareous nannoplankton zonation. In Proceedings of the Second Planktonic Conference, Rome, 1970. Edited by F.A. Edizioni Tecnoscienza, Rome, pp. 739-785.

Martini, E., AND MüLler, C. 1986. Current Tertiary and Quaternary calcareous nannoplankton stratigraphy and correlations. Newsletter on Stratigraphy, 1, pp. 49-60.

McIver, N.L. 1972. Mesozoic-Cenozoic stratigraphy of the Nova Scotia Shelf. Canadian Journal of Earth Sciences, 9, pp. 54-70.

Miller, K.G., Kominz, M.A., Browning, J.V., Wright, J.D, Mountain, G.S., Katz, M.E., Sugarman, P.J, Cramer, B.S., Christie-Blick, N., and Pekar, S.F. 2005. The Phanerozoic record of global sea-level change. Science, 310, pp. 1293-1298.

OgG, J. G., Agterberg, F. P., and Gradstein, F. M. 2005. The Cretaceous Period. In A geologic time scale 2004. Edited by F.M. Gradstein, J.G. Ogg, and A.G. Smith. Cambridge University Press, Cambridge, pp. 344-383.

Ogg, J. G., Lugowski, A., and Gradstein, F. 2008. Time Scale Creator, version 3.7.URL <http://www.tscreator.com>, May 2008.

Perch-Nielsen, K. 1985a. Cenozoic calcareous nannofossils. In Plankton stratigraphy. Edited by H.M. Bolli, J.B. Saunders, and K. Perch-Nielsen. Cambridge University Press, pp. 427-554.

Perch-Nielsen, K. 1985b. Mesozoic calcareous nannofossils. In Plankton stratigraphy. Edited by H.M. Bolli, J.B. Saunders, and K. Perch-Nielsen. Cambridge University Press, pp. 329-426.

Powell, T.G. 1982. Petroleum geochemistry of Verrill Canyon Formation, a source for Scotian Shelf hydrocarbons. Bulletin of Canadian Petroleum Geology, 30, pp. 167-179.

Powell, A.J. 1986. A dinoflagellate cyst biozonation for the Late Oligocene to Middle Miocene succession of the Langhe region, northwest Italy. American Association of Stratigraphic Palynologists, Contribution Series, 17, pp. 105-127.
Powell, A.J., Brinkhuis, H., ANd Bujak, J.P. 1996. Upper Paleocene-Lower Eocene dinoflagellate cyst sequence stratigraphy of southeast England. In Correlations of the early Paleogene in northwest Europe. Edited by R.W.O. Knox, R.M. Corfield, and R.E. Dunay. Geological Society Special Publication 101, pp. 145-183.

SHIMELD, J. 2004. A comparison of salt tectonic subprovinces beneath the Scotian Slope and Laurentian Fan. In Salt-sediment interactions and hydrocarbon prospectivity: concepts, applications and case studies for the 21st century. Edited by P. Post. Gulf Coast Society Section of the Society of Economic Paleontologists and Mineralogists, 24th Annual Bob F. Perkins Research Conference, Houston, Texas, December 5-8, 2004. (Extended Abstracts Volume on CD).

SissingH, W. 1977. Biostratigraphy of Cretaceous calcareous nannoplankton. Geologie en Mijnbouw, 56, pp. 37-65.

Stradner, H., AND SteInMETz. J. 1984. Cretaceous calcareous nannofossils from the Angola basin, DSDP Site 530. Initial Reports of the Deep Sea Drilling Project, 75, pp. 565-649.

Thomas, F.C. 1991. Report on the Cenozoic biostratigraphy (foraminifera) and depositional environments of the Shell Onondaga E-84 well, Scotian Shelf, from 907 to 3977' (top of Cretaceous). Unpublished Geological Survey of Canada Report no. BAS-PAL.9-91FCT, 5 p.

Thomas, F.C. 2001. Cenozoic micropaleontology of three wells, Scotian Shelf and Slope. Geological Survey of Canada Open File Report 4014, 36 p.

Thomas, F.C. 2003a. Report on the Cenozoic biostratigraphy (foraminifera) and depositional environments of PetroCanada-Mobil Hesper I-52, (eastern Scotian Shelf), from 990 to 4170'(Cretaceous). Unpublished Geological Survey of Canada Report no. MRG-PAL.6-2003FCT, 9 p.

Thомas, F.C. 2003b. Mesozoic foraminiferal and ostracod biostratigraphy of Petro-Canada-Mobil Hesper I-52, (eastern Scotian Shelf). Unpublished Geological Survey of Canada Report no. MRG-PAL.9-2003FCT, 6 p.

Thomas, F.C. 2003c. Report on the Cenozoic biostratigraphy (foraminifera) and depositional environments of the Petro-Canada et al. Shelburne G-29 well (Scotian Shelf), from 1620-2760m (Cretaceous). Unpublished Geological Survey of Canada Report no. MRG-PAL.2-2003FCT, 9 p.

Thomas, F.C. 2005. Oligocene benthic foraminifera from the Paleogene Wenonah Canyon, Scotian Shelf - normal versus canyon assemblages. Atlantic Geology, 41, pp. 1-16.

TJalsma, R.C., And Lohmann, G.P. 1983. Paleocene-Eocene bathyal and abyssal benthic foraminifera from the Atlantic Ocean. Micropaleontology, Special Publication 4, 90 p.

Toumarkine, M., And Luterbacher, H.1985. Paleocene and Eocene planktic foraminifera. In Plankton stratigraphy. Edited by H.M. Bolli, J.B. Saunders, and K. PerchNielsen. Cambridge University Press, Cambridge, U.K., pp. 87-154.

VAROL, O. 1992. Taxonomic revision of the Polycyclolithaceae and its contribution to Cretaceous biostratigraphy. Newsletter on Stratigraphy, 27, pp. 93-127.

VAROL, O. 1998. Paleogene. In Calcareous nannofossil biostra- 
tigraphy. Edited by P.R. Bown. British Micropalaeontological Society \& Chapman \& Hall, London, pp. 200-224.

VeKshina, V.N. 1959. Coccolithophoridae of the Maastrichtian deposits of the west Siberian lowlands. Transactions of the Siberian Institute of Geology, Geophysics and Mineral Resources (SNIIGGIMS), 2, pp. 56-77.

Wade, J. A., And MacLean, B. 1990. Chapter 5. The geology of the southeastern margin of Canada. In Geology of the continental margin of eastern Canada. Edited by M.J. Keen and G.L. Williams. Geological Survey of Canada, Geology of Canada 2 (also Geological Society of America, Geology of North America, I-1, pp. 167-238.

Wade, J.A., MacLean, B.C., ANd Williams, G.L. 1995. Mesozoic and Cenozoic stratigraphy, eastern Scotian Shelf: new interpretation. Canadian Journal of Earth Sciences, 32, pp. 1462-1473.

Williams, G. L. 1975. Dinoflagellate and spore stratigraphy of the Mesozoic-Cenozoic, offshore eastern Canada. In Offshore geology of eastern Canada. Edited by W.J.M. van der Linden, and J.A. Wade. Geological Survey of Canada Paper 74-30, pp. 107-161.

Williams, G.L., AND BuJaK, J. 1977. Cenozoic palynostratigraphy of offshore eastern Canada. American Association of Stratigraphic Palynologists, Contribution Series, no.5A, pp. 14-47, pl. 1-5.
Williams, G.L., Ascoli, Barss, M.S., BujaK, J.P., Davies, E.H., Fensome, R.A., ANd Williamson, M.A. 1990. Chapter 3. Biostratigraphy and related studies. In Geology of the continental margin of eastern Canada. Edited by M.J. Keen and G.L. Williams. Geological Survey of Canada, Geology of Canada 2 (also Geological Society of America, Geology of North America I-1), pp. 89-137.

Williams, G.L., Bujak, J.P, Brinkhuis, H., Fensome, R.A., and Weegink, J.W. 1999. Mesozoic-Cenozoic dinoflagellate cyst course, Urbino, Italy, May 17-22, 1999. (Unpublished short course manual).

Williams, G.L., Brinkhuis, H., Pearce, M.A., Fensome, R.A., AND WEEGINK, J.W. 2004. Southern Ocean and global dinoflagellate cyst events compared: index events for the Late Cretaceous-Neogene. Proceedings of the Ocean Drilling Program, Scientific Results, v.189, p.1-98. (URL < http: //www.odp.tamu.edu/publications/189_SR/107/107.htm>. September 2004.

Williams, H., And Grant, A.C. 1998. Tectonic assemblages, Atlantic Region, Canada. Geological Survey of Canada, Open File 3657.

YounG, J. R. 1998. Neogene. In Calcareous nannofossil biostratigraphy. Edited by P.R. Bown. British Micropalaeontological Society \& Chapman \& Hall, London, pp. 225-265.

Editorial responsibility: Sandra M. Barr

\section{APPENDIX 1}

\section{Nannofossils}

Ahmuellerella octoradiata (Górka 1957) Reinhardt 1966

Amaurolithus delicatus Gartner \& Bukry 1975

Axopodorhabdus albianus (Black 1967) Wind \& Wise in Wise \& Wind 1977

Broinsonia parca subspecies constricta Hattner et al. 1980

Broinsonia parca subspecies parca (Stradner 1963) Bukry 1969

Calcidiscus macintyrei (Bukry \& Bramlette 1969) Loeblich \& Tappan 1978

Campylosphaera dela (Bramlette \& Sullivan 1961) Hay \& Mohler 1967

Ceratolithoides aculeus (Stradner 1961) Prins \& Sissingh in Sissingh 1977

Ceratolithoides kamptneri Bramlette \& Martini 1964

Chiasmolithus altus Bukry \& Percival 1971

Chiasmolithus gigas (Bramlette \& Sullivan 1961) Radomski 1968

Chiasmolithus grandis (Bramlette \& Riedel 1954) Radomski 1968

Chiasmolithus oamaruensis (Deflandre 1954) Hay et al. 1966

Chiasmolithus solitus (Bramlette \& Sullivan 1961) Locker 1968
Clausicoccus fenestratus (Deflandre in Deflandre \& Fert 1954) Prins 1979

Corollithion kennedyi Crux 1981

Coronocyclus nitescens (Kamptner 1963) Bramlete \& Wilcoxon 1967

Cribrocorona gallica (Stradner 1963) Perch-Nielsen 1973

Cribrosphaerella daniae Perch-Nielsen 1973

Cyclicargolithus floridanus (Roth \& Hay in Hay et al. 1967) Bukry 1971

Cyclococcolithus formosus Kamptner 1963

Daktylethra punctulata Gartner in Gartner \& Bukry 1969

Discoaster barbadiensis Tan 1927

Discoaster berggrenii Bukry 1971

Discoaster deflandrei Bramlette \& Riedel 1954

Discoaster kuepperi Stradner 1959

Discoaster lodoensis Bramlette \& Riedel 1954

Discoaster loeblichii Bukry 1971

Discoaster multiradiatus Bramlette \& Riedel 1954

Discoaster pentaradiatus Tan 1927

Discoaster petaliformis Moshkovitz \& Erlich 1980

Discoaster quinqueramus Gartner 1969

Discoaster saipanensis Bramlette \& Riedel 1954

Eiffellithus eximius (Stover 1966) Perch-Nielsen 1968

Eprolithus apertior Black 1973 
Eprolithus eptapetalus Varol 1992

Eprolithus floralis (Stradner 1962) Stover 1966

Eprolithus octopetalus Varol 1992

Fasciculithus involutus Bramlette \& Sullivan 1961

Fasciculithus janii Perch-Nielsen 1971

Fasciculithus tympaniformis Hay \& Mohler in Hay et al. (1967)

Gartnerago nanum Thierstein 1974

Gartnerago theta (Black in Black \& Barnes 1959) Jakubowski 1986

Helicospahera ampliaperta Bramlette \& Wilcoxon 1967

Helicosphaera selli (Bukry \& Bramlette 1969) Jafar \& Martini 1975

Heliolithus riedelii Bramlette \& Sullivan 1961

Isthmolithus recurvus Deflandre in Deflandre \& Fert 1954

Liliasterites spp. Stradner \& Steinmetz 1984

Lithastrinus septenarius Forchheimer 1972

Lithraphidites quadratus Bramlette \& Martini 1964

Lophodolithus mochloporus Deflandre in Deflandre \& Fert 1954

Lophodolithus nascens Bramlette \& Sullivan 1961

Microstaurus chiastius (Worsley 1971) Grün in Grün \& Allemann 1975

Micula murus (Martini 1961) Bukry 1973

Micula prinsii Perch-Nielsen 1979

Micula spp. Vekshina 1959

Minylitha convallis Bukry 1973

Nannotetrina fulgens (Stradner in Martini \& Stradner 1960) Achutchan \& Stradner 1969

Neochiastozygus imbriei Haq \& Lohmann 1976

Nephrolithus frequens Górka 1957

Owenia hillii Crux 1991

Pemma papillata Martini 1959

Prinsius martini (Perch-Nielsen 1969) Haq 1971

Pseudoemiliania lacunosa (Kamptner 1963) Gartner 1969

Pseudoemiliania ovata (Bukry 1973) Young 1998

Quadrum gartneri Prins \& Perch-Nielsen in Manivit et al. 1977

Radiolithus planus Stover 1966

Reinhardtites anthophorus (Deflandre 1959) Perch-Nielsen 1968

Reinhardtites levis Prins \& Sissingh in Sissingh 1977

Reticulofenestra bisecta (Hay et al. 1966) Roth 1970

Reticulofenestra pseudoumbilica (Levin 1965) Martini \& Ritzkowski 1968

Reticulofenestra reticulata (Gartner \& Smith 1967) Roth \& Thierstein 1972

Reticulofenestra rotaria Theodoridis 1984

Reticulofenestra umbilica (Levin 1965) Martini \& Ritzkowski 1968

Rhabdosphaera inflata Bramlette \& Sullivan 1961

Rhagodiscus achlyostaurion (Hill 1976) Doeven 1983

Rhagodiscus asper (Stradner 1963) Reinhardt 1967

Sphenolithus abies Deflandre in Deflandre \& Fert 1953

Sphenolithus belemnos Bramlette \& Wilcoxon 1967

Sphenolithus editus Perch-Nielsen 1978
Sphenolithus spiniger Bukry 1971

Sphenolithus furcatolithoides Locker 1967

Sphenolithus heteromorphus Deflandre 1953

Stoverius achylosus (Stover 1966) Perch-Nielsen 1986

Toweius eminens (Bramlette \& Sullivan 1961) Perch-Nielsen 1971

Toweius magnicrassus Bukry (1971) Romein 1979

Toweius tovae Perch-Nielsen 1971

Tranolithus orionatus (Reinhardt 1966) Reinhardt 1966

Triquetrorhabdulus carinatus Martini 1965

Uniplanarius sissinghii Perch-Nielsen 1986

Uniplanarius trifidus (Stradner in Stradner \& Papp 1961)

Hattner \& Wise 1980

Zygrhablithus bijugatus (Deflandre in Deflandre \& Fert 1954)

Deflandre 1959

Watznaueria britannica (Stradner 1963) Reinhardt 1964

\section{Dinocysts}

Achilleodinium biformoides (Eisenack 1954) Eaton 1976

Achomosphaera alcicornu (Eisenack 1954) Davey and Williams $1966 \mathrm{a}$

Achomosphaera andalousiensis Jan du Chêne 1977

Adnatosphaeridium vittatum Williams and Downie 1966c

Alisogymnium euclaense (Cookson and Eisenack 1970a) Lentin and Vozzhennikova 1990

Alterbidinium acutulum (Wilson 1967) Lentin and Williams 1985

Apectodinium homomorphum (Deflandre and Cookson 1955) Lentin and Williams 1977b

Apteodinium australiense (Deflandre and Cookson 1955) Williams 1978

Apteodinium spiridoides Benedek 1972

Areoligera circumsenonensis Fensome et al. in press

Areoligera gippingensis Jolley 1992

Axiodinium prearticulatum Williams, Damassa, Fensome and Guerstein in Fensome et al. in press

Barssidinium graminosum Lentin et al. 1994

Barssidinium pliocenicum (Head 1993) Head 1994

Batiacasphaera micropapillata Stover 1977

Callaiosphaeridium asymmetricum (Deflandre \& Courteville 1939) Davey \& Williams 1966 b

Canningia reticulata Cookson and Eisenack 1960b

Cerebrocysta waipawaensis (Wilson 1988) Fensome et al. in press

Cerodinium diebelii (Alberti 1959) Lentin and Williams 1987

Cerodinium glabrum (Gocht 1969) Fensome et al. in press

Cerodinium speciosum (Alberti 1959) Lentin and Williams 1987

Chatangiella tripartita (Cookson and Eisenack 1960a) Lentin and Williams 1976

Chichaouadinium vestitum (Brideaux 1971) Bujak and Davies 1983

Chiropteridium galea (Maier 1959) Sarjeant 1983

Chlamydophorella nyei Cookson and Eisenack 1958 
Cleistosphaeridium ancyreum (Cookson and Eisenack 1965)

Eaton et al. 2001

Cleistosphaeridium diversispinosum Davey et al. 1966

Cordosphaeridium cantharellus (Brosius 1963) Gocht 1969

Cordosphaeridium delimurum Fensome et al. in press

Cordosphaeridium fibrospinosum Davey and Williams 1966b

Cordosphaeridium gracile (Eisenack 1954) Davey and Williams $1966 \mathrm{~b}$

Coronifera oceanica Cookson and Eisenack 1958

Cousteaudinium aubryae de Verteuil and Norris 1996

Cyclonephelium brevispinatum (Millioud 1969) Below 1981

Cyclonephelium distinctum Deflandre and Cookson 1955

Cyclonephelium vannophorum Davey 1969a

Damassadinium californicum (Drugg 1967) Fensome et al. 1993

Dapsilidinium pseudocolligerum (Stover 1977) Bujak et al. 1980

Deflandrea eocenica Balteş 1969 ex Lentin and Williams 1973

Deflandrea phosphoritica Eisenack 1938a

Dinogymnium acuminatum Evitt et al. 1967

Dinopterygium alatum (Cookson and Eisenack 1962) Fensome et al. in press

Diphyes colligerum (Deflandre and Cookson 1955) Cookson 1965

Diphyes ficusoides Islam 1983

Disphaerogena carposphaeropsis Wetzel 1933

Distatodinium paradoxum (Brosius 1963) Eaton 1976

Elytrocysta druggii Stover and Evitt 1978

Eocladopyxis peniculata Morgenroth 1966

Epelidosphaeridia spinosa Cookson and Hughes 1964 ex Davey $1969 \mathrm{a}$

Exochosphaeridium insigne de Verteuil and Norris 1996

Glaphyrocysta divaricata (Williams and Downie 1966c) Stover and Evitt 1978

Glaphyrocysta extensa Fensome et al. in press

Glaphyrocysta exuberans (Deflandre and Cookson 1955 ex Eaton 1976) Stover and Evitt 1978

Glaphyrocysta retiintexta (Cookson 1965) Stover and Evitt 1978

Hafniasphaera delicata Fensome et al. in press

Heteraulacacysta pustulata Jan du Chêne and Adediran 1985

Heterosphaeridium difficile (Manum and Cookson 1964) Ioannides 1986

Homotryblium plectilum Drugg and Loeblich 1967

Homotryblium tenuispinosum Davey and Williams 1966b

Hystrichokolpoma grimmertingenense de Coninck 2001

Hystrichokolpoma rigaudiae Deflandre and Cookson 1955

Hystrichokolpoma truncatum Biffi and Manum 1988

Hystrichosphaeridium bowerbankii Davey and Williams 1966b

Hystrichosphaeridium tubiferum (Ehrenberg 1838) Deflandre 1937

Hystrichosphaeropsis obscura Habib 1972

Impletosphaeridium capitatum Fensome et al. in press

Isabelidinium cooksoniae (Alberti 1959) Lentin and Williams $1977 \mathrm{a}$
Isabelidinium glabrum (Cookson and Eisenack 1969) Lentin and Williams 1977a

Kiokansium unituberculatum (Tasch et al. 1964) Stover and Evitt 1978

Kiokansium williamsii Singh 1983

Kleithriasphaeridium cooksoniae (Singh 1971) Fensome et al. in press

Kleithriasphaeridium loffrense Davey and Verdier 1976

Kleithriasphaeridium perforatum (Firth 1993) Fensome et al. in press

Labyrinthodinium truncatum Piasecki 1980.

Lentinia serrata Bujak in Bujak et al. 1980

Licracysta corymbus Fensome et al. 2007

Litosphaeridium siphoniphorum (Cookson and Eisenack 1958) Davey and Williams 1966b

Manumiella seelandica (Lange 1969) Bujak and Davies 1983

Membranophoridium aspinatum Gerlach 1961

Mendicodinium? robustum Zevenboom and Santarelli in Zevenboom 1995 ex Fensome et al. in press

Minisphaeridium latirictum (Davey and Williams 1966b)

Fensome et al. in press

Nyktericysta tripenta (Bint 1986) Fensome et al. in press

Odontochitina costata Alberti 1961

Odontochitina porifera Cookson 1956

Odontochitina rhakodes Bint 1986

Oligokolpoma tubulus Fensome et al. in press

Oligosphaeridium albertense (Pocock 1962) Davey and Williams 1969

Oligosphaeridium perforatum (Gocht 1959) Davey and Williams 1969

Oligosphaeridium totum Brideaux 1971

Operculodinium centrocarpum (Deflandre and Cookson 1955)

Wall 1967

Palaeocystodinium bulliforme Ioannides 1986

Palaeocystodinium golzowense Alberti 1961

Palaeocystodinium obesum Fensome et al. in press

Palaeocystodinium teespinosum Fensome et al. in press

Palaeohystrichophora infusorioides Deflandre 1935

Palaeohystrichophora palaeoinfusa Fensome et al. in press

Palaeoperidinium cretaceum (Pocock 1962 ex Davey 1970) Lentin and Williams 1976

Palaeoperidinium pyrophorum (Ehrenberg 1838 ex Wetzel 1933a) Sarjeant 1967

Palynodinium grallator Gocht 1970

Pentadinium laticinctum Gerlach 1961

Pentadinium sabulum Fensome et al. in press

Pervosphaeridium granaciculare Fensome et al. in press

Phthanoperidinium coreoides (Benedek 1972) Lentin and Williams 1976

Pierceites pentagonus (May 1980) Habib and Drugg 1987

Raetiaedinium truncigerum (Deflandre 1937) Kirsch 1991

Reticulatosphaera actinocoronata (Benedek 1972) Bujak and Matsuoka 1986

Rhombodinium perforatum (Jan du Chêne and Châteauneuf 1975) Lentin and Williams 1977b 
Rottnestia borussica (Eisenack 1954) Cookson and Eisenack 1961b

Schematophora speciosa Deflandre and Cookson 1955

Senoniasphaera rotundata Clarke and Verdier 1967

Sepispinula huguoniotii (Valensi 1955) Islam 1993

Spinidinium densispinatum Stanley 1965

Spiniferites ovatus Matsuoka 1983

Spiniferites ramosus (Ehrenberg 1838) Mantell 1854

Spongodinium delitiense (Ehrenberg 1838) Deflandre 1936

Subtilisphaera perlucida (Alberti 1959) Jain and Millepied 1973

Surculosphaeridium longifurcatum (Firtion 1952) Davey et al. 1966

Talladinium clathratum (Eisenack 1938a) Williams, Damassa, Fensome and Guerstein in Fensome et al. in press

Tanyosphaeridium xanthiopyxides (Wetzel 1933b ex Deflandre 1937) Stover and Evitt 1978

Thalassiphora pelagica (Eisenack 1954) Eisenack and Gocht 1960

Trichodinium castanea Deflandre 1935 ex Clarke and Verdier 1967

Trithyrodinium evittii Drugg 1967

Unipontidinium aquaeductus (Piasecki 1980) Wrenn 1988

Vesperopsis mayii Bint 1986

Wetzeliella articulata Wetzel in Eisenack 1938a

Wetzeliella caviarticulata Williams, Damassa, Fensome and Guerstein in Fensome et al. in press

Wetzeliella gochtii Costa and Downie 1976

Wetzeliella simplex (Bujak 1979) Lentin and Vozzhennikova 1989

Wetzeliella symmetrica Weiler 1956
Xenascus ceratioides (Deflandre 1937) Lentin and Williams 1973

Xenascus perforatus (Vozzhennikova 1967) Yun Hyesu 1981

\section{Other Palynomorphs}

Cicatricosisporites minutaestriatus (Bolkhovitina 1961) Pocock 1964

Cingutriletes tyriskos Fensome et al. in press

Paralecaniella indentata (Deflandre and Cookson 1955) Cookson and Eisenack 1970b

\section{Foraminifera}

Acarinina densa (Cushman 1925)

Acarinina spinuloinflata (Bandy 1949)

Catapsydrax dissimilis (Cushman and Bermudez 1937)

Globigerina praebulloides Blow 1959

Globocassidulina subglobosa (Brady 1884)

Globoquadrina venezuelana (Hedberg 1937)

Glomospira corona (Cushman and Jarvis 1929)

Hoeglundina elegans (d'Orbigny 1826)

Lenticulina americana (Cushman 1923)

Lenticulina whitei (Tjalsma and Lohmann 1983)

Martinotiella communis (d'Orbigny 1846)

Melonis barleeanum (Williamson 1858)

Melonis pompilioides (Bandy 1961)

Neogloboquadrina continuosa (Blow 1959)

Nuttalinella florealis (White 1928)

Pseudohastigerina micra (Cole 1927)

Pseudohastigerina wilcoxensis (Cushman and Ponton 1932)

Pullenia bulloides (d’Orbigny 1826)

Spiroplectammina navarroana (Cushman 1932)

Spiroplectammina spectabilis (Grzybowski 1898)

Uvigerina peregrina (Cushman 1923)

\section{PLEASE NOTE}

The authors may be contacted for larger printed versions of appendices 2-8. 
APPENDIX 2

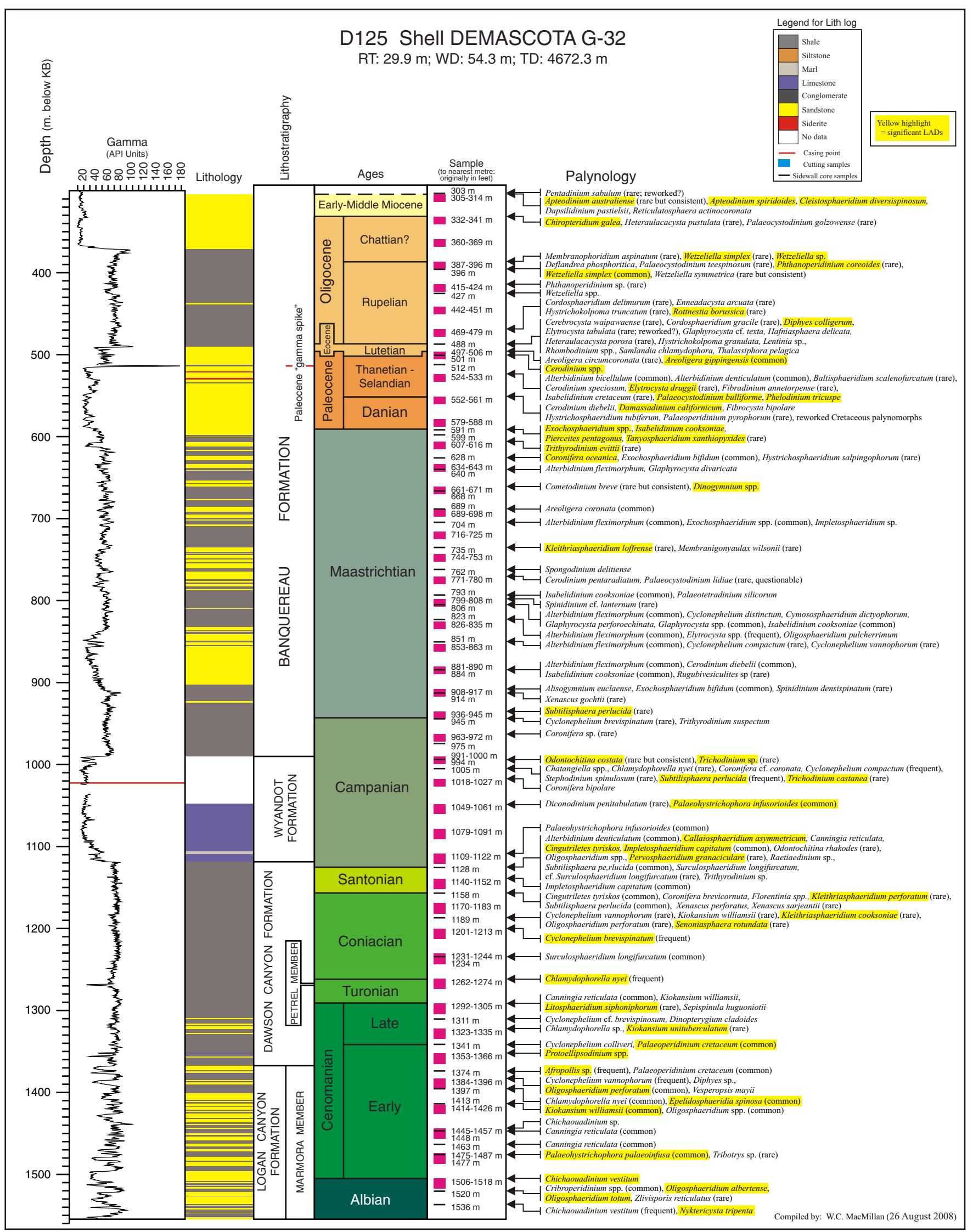


APPENDIX 3

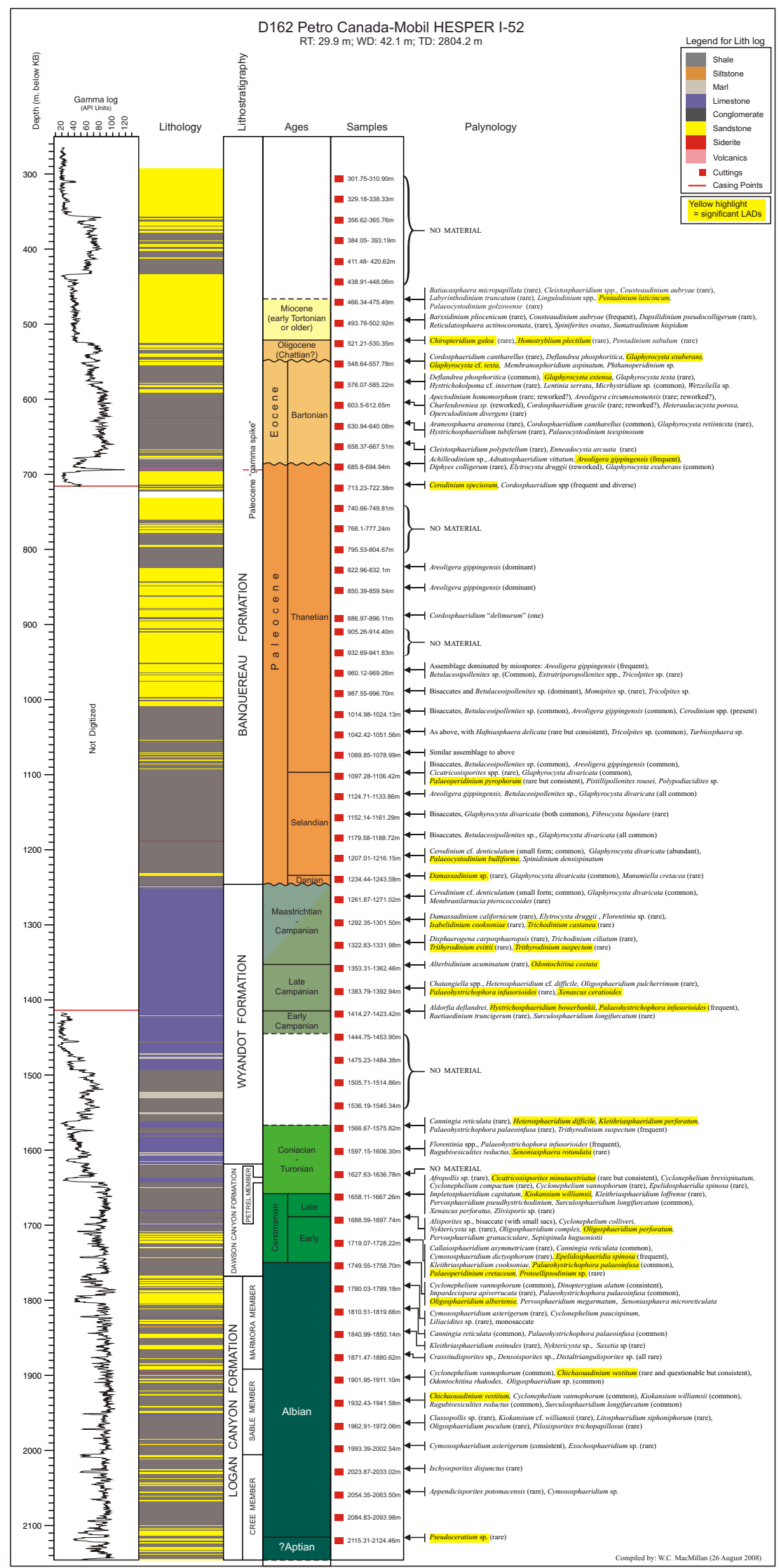




\section{APPENDIX 4}

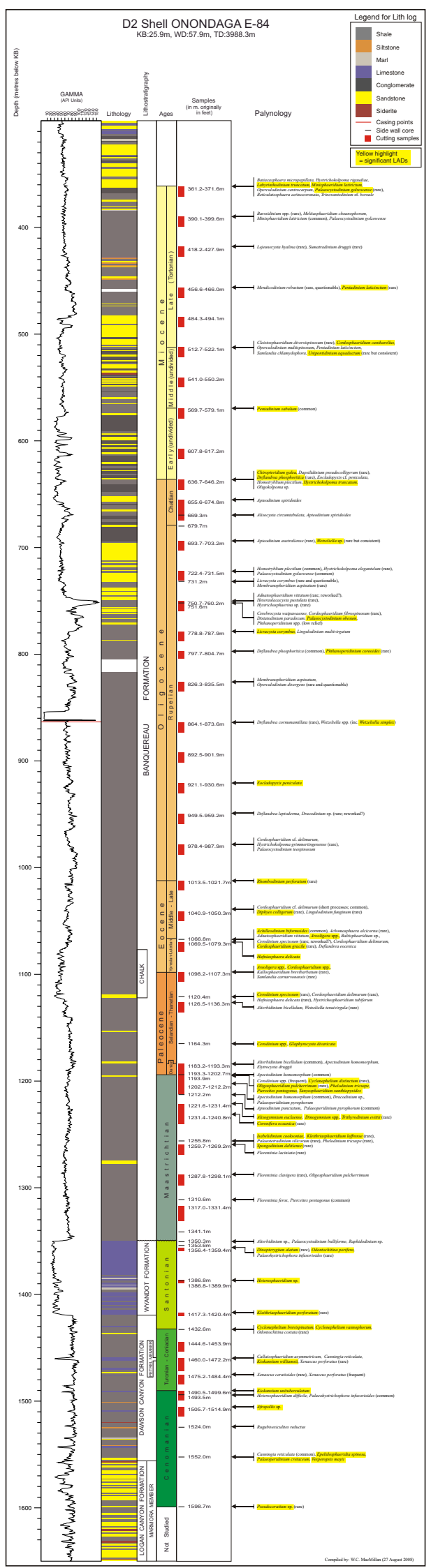




\section{APPENDIX 5}

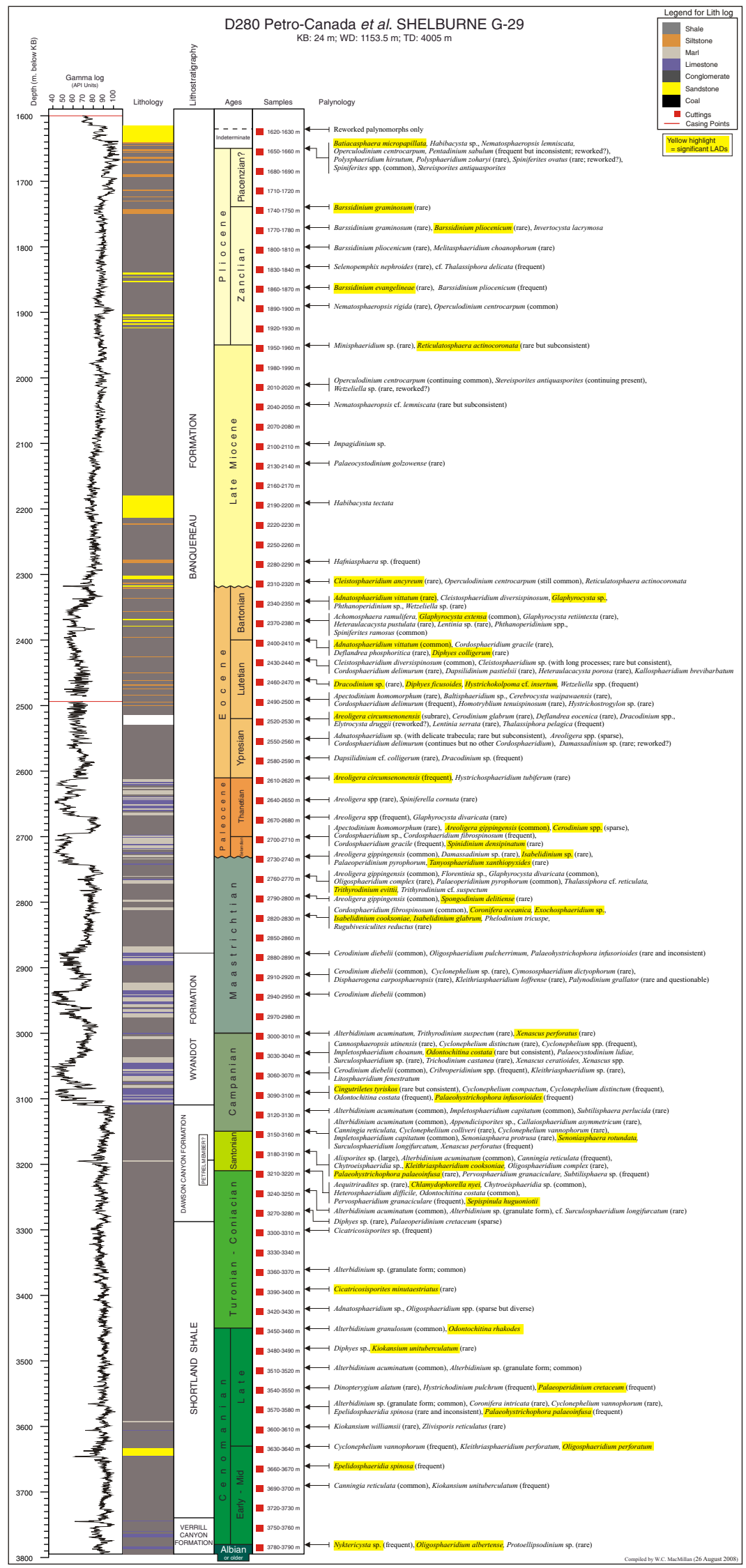




\section{APPENDIX 6}




APPENDIX 7

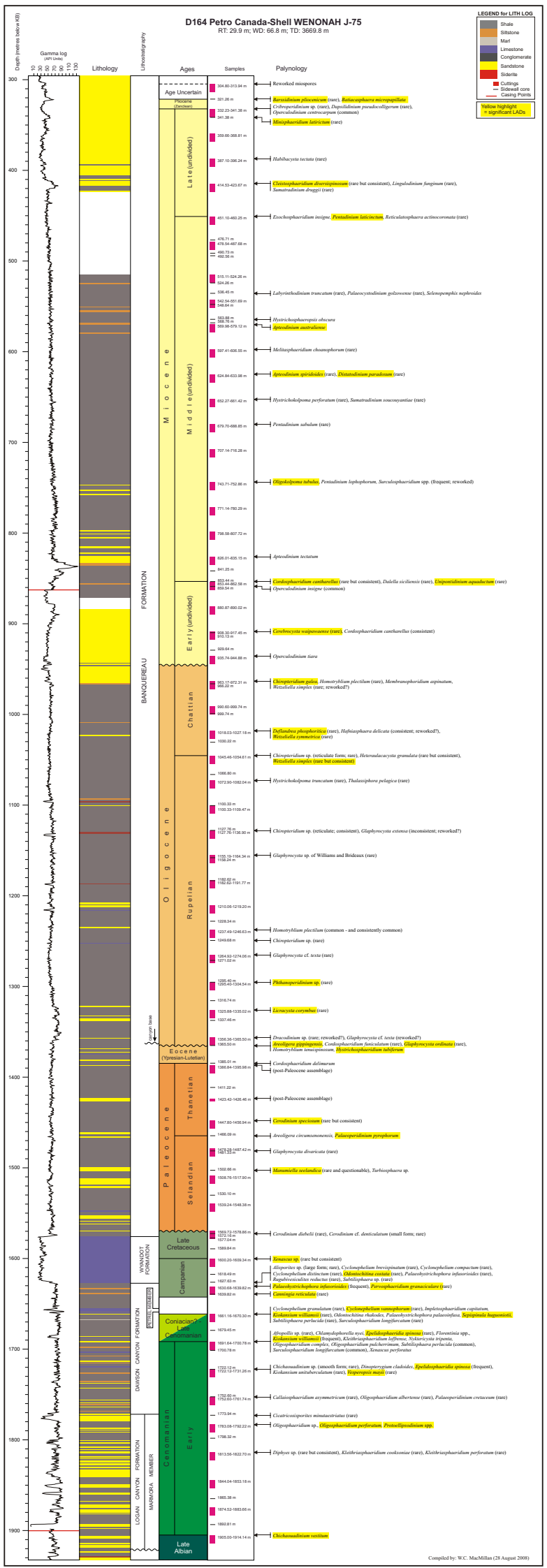


APPENDIX 8

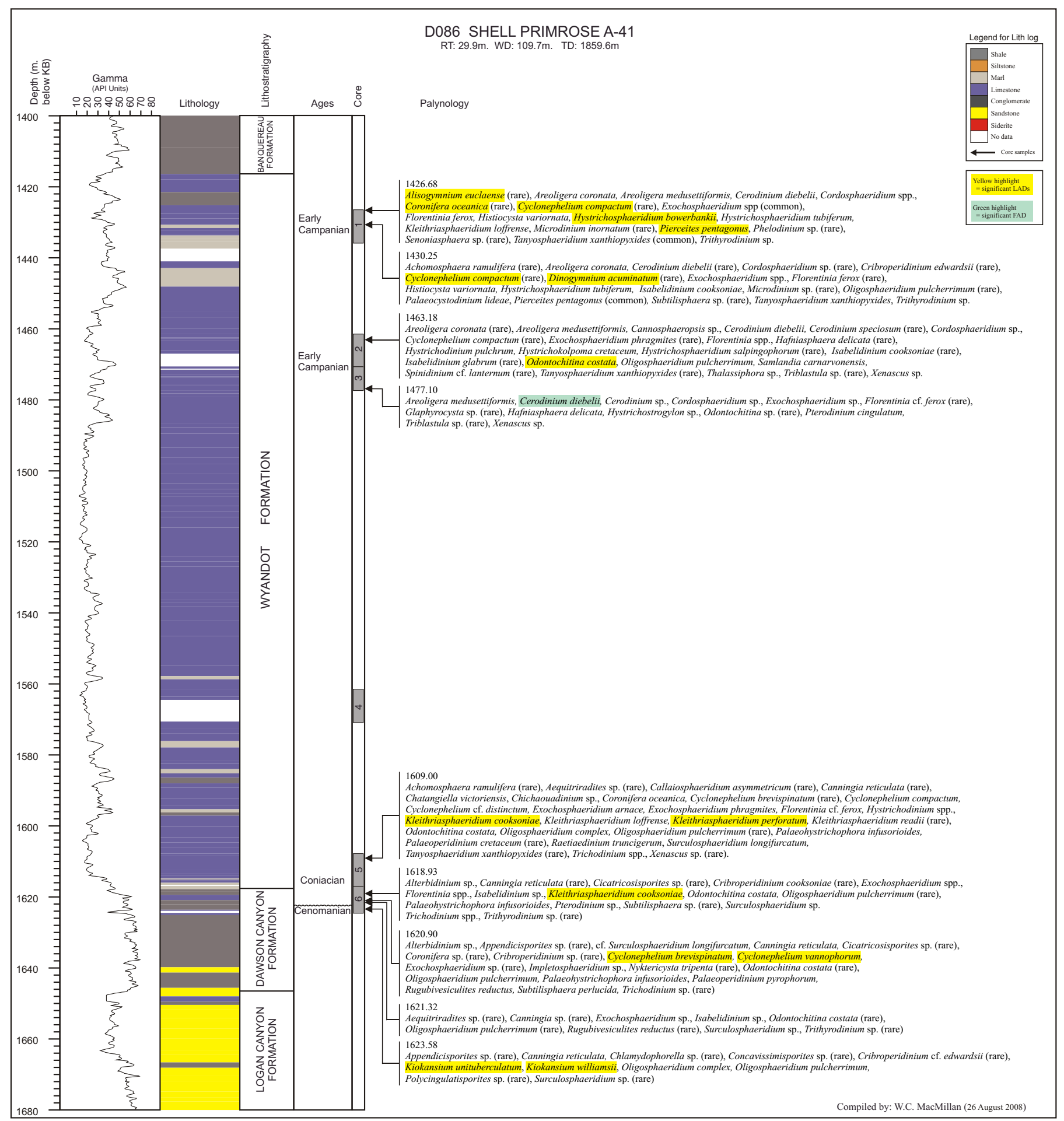

